\title{
Simulation Analysis for an Optimal Environmental Policy Including the Introduction of New Technologies
}

\author{
Takeshi Mizunoya ${ }^{1, *}$, Katsuhiro SAKUraI**, Shintaro Kobayashi* \\ and Yoshiro Higano*
}

\begin{abstract}
In this study, we analyze a dynamic optimal policy and evaluate new technologies to improve the water quality of a lake, considering both the total ecological system in and around the lake and situational changes over a certain period of time. Three sub-models (the socio-economic model, the material flow balance model and the water cycle model) and one objective function were specified in order to analyze optimal policies to improve the water quality of Lake Kasumigaura. The socio-economic model describes the social and economic activities in the catchment area and the relationship between the activities and the emission of pollutants. The material flow balance model describes change in the amount of generation and flow of pollutants in the lake and the rivers. The optimal policies were derived so as to maximize the objective function (GRP) subject to the structural equations that describe both the ecosystem and socioeconomic system. The pollutants measured in this study were nitrogen, phosphorus and COD which strongly affect the deterioration of water quality.
\end{abstract}

JEL classification: Q25, Q55, Q58

Keywords: New Technology, Government Policy, Environmental Quality, Modeling, Simulation

\section{Introduction}

The quality of water in Lake Kasumigaura (Fig. 1) has been deteriorating since the 1970's by pollution discharged from socio-economic activities of the catchment area. Recently, many engineering experts are working to develop technologies in order to solve the problem. Many studies have been undertaken in efforts to prevent environmetal problems or water deterioration of the lake. For example, Baumol et al. [3] and Oka [8] analyzed the political aspects of the environmental problems. Higano and Yoneta [5] and Takagi et al. [9] conducted simple simulation analyses to evaluate water purification policies. Also, many new technologies have been improved (Inamori [6], Yoshida et al. [11] etc.). However, no studies analyze the environmental policies and evaluate technologies simultaneously with a large scale simulation model. In this study, we propose a synthesized environmental management policy by computer simulation that includes the introduction of new technologies to improve the water quality of the lake considering both the total ecological system in and around the lake and social environmental changes over a specific period. Three sub-models (material flow balance model, socio-economic model and water cycle model) and one objective function (Regional GDP) are specified in order to predict the optimal policy to

\footnotetext{
1 This research summarizes as a paper a part of research being done as "The Project for Water Environment Renovation of Lake Kasumigaura”.

* University of Tsukuba

** Ocean Policy Research Foundation

Received : 3 March 2006 Accepted: 17 December 2006
}

(C) 日本地域学会 (JSRSAI) 2007 


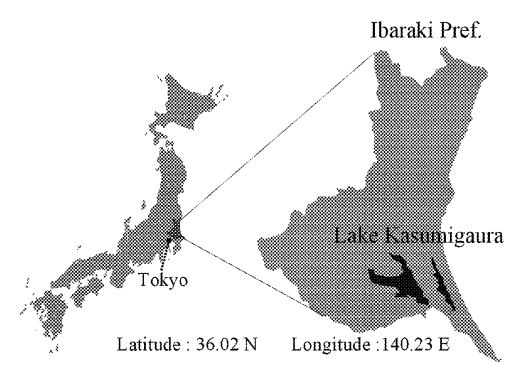

Fig. 1 Location of Lake Kasumigaura

improve the water quality of Lake Kasumigaura. The simulation running period was from 19992003 (total 5 years) and the pollutants measured in this study are total nitrogen, total phosphorus and COD.

\section{Simulation Model}

\subsection{Sub-basin of the Major River and Municipality in the Kasumigaura Basin}

The area of the municipality and sub-basin does not necessarily coincide. When the area of a municipality belongs to several sub-basins, we estimated the ratios of rainfall in the area that flows into the rivers of the sub-basins. The estimation is based on the official data published in 1999 by The Science and Technology Promotion Foundation of Ibaraki [10] (Table 1). The fifteen major rivers in the Basin are structured into the model assuming the other small rivers in the sub-basins flow into one of the major rivers.Indices of municipalities in Table 1 are made so that those having smaller number are located upper the major rivers than those having large.

\subsection{Clasifycation of water pollutant sources}

We classified water pollutant generation source into 3 categories, namely household, non-point and industrial wastewater. The household wastewater disposal system was divided into 8 categories of household wastewater generation sources, land use into 5 categories of non-point generation sources and industry into 5 categories of industrial activity generation sources (See Tables 24). "Other Land Use" in Table 3 and "Other Industry" in Table 4 emitts no water pollutnats. It is assumed that the population that uses septic tanks and night soil septic tank do not grow as the trade of septic tank has voluntarily restrained provision of the service and facility since 1999.

\subsection{Policy measures against water pollutants}

The policy measures listed in Table 5 were assumed in the simulation, measures the Ibaraki Prefectural Government should select to make a hybrid policy for the most efficient improvement in the water quality of the Lake Kasumigaura. Most of these measures are currently adopted and several new technologies are added to the list. It is also assumed that the annual budget that the government spends directly and indirectly for improvement is limited to 20 billion Japanese yen.

\subsection{Skeleton of the Simulation Model}

The model is composed of three sub-models and one objective function. The material flow balance model describes how the pollutants flow into the rivers and lake.The socio-economic model describes the social and economic activities in the catchment areas and the relationship between the activities and the emission of pollutants. The water cycle model describes how much water is generated and the flow of water in the catchment areas. All the policy measures to improve water quality directly, indirectly and potentially are built in the mode as alternatives that provide an optimal hybrid of the policy measures. The model simulates the socio-economic activities when 
Table 1. Classification of Taget Area

\begin{tabular}{|c|c|c|c|c|c|c|c|c|c|c|c|c|c|}
\hline \multicolumn{2}{|c|}{ Water Areas } & \multicolumn{2}{|r|}{ Rivers } & \multicolumn{2}{|c|}{$\begin{array}{c}\text { Cities, Towns and } \\
\text { Villages }\end{array}$} & \multirow{2}{*}{\begin{tabular}{|c|} 
Notes \\
Proportion of \\
the area \\
included in \\
the \\
catchment) \\
$(\%)$
\end{tabular}} & \multicolumn{2}{|c|}{ Water Areas } & \multicolumn{2}{|r|}{ Rivers } & \multicolumn{2}{|c|}{$\begin{array}{c}\text { Cities, Towns and } \\
\text { Villages }\end{array}$} & \multirow{2}{*}{$\begin{array}{c}\text { Notes } \\
\text { Proportion of } \\
\text { the area } \\
\text { included in } \\
\text { the } \\
\text { catchment) } \\
(\%)\end{array}$} \\
\hline No. & Name & No. & Name & No. & Name & & No. & Name & No. & Name & No. & Name & \\
\hline \multirow{11}{*}{1} & \multirow{11}{*}{$\begin{array}{l}\text { Coast of } \\
\text { Tsuchiura }\end{array}$} & \multirow{10}{*}{1} & \multirow{10}{*}{$\begin{array}{l}\text { Sakura } \\
\text { River }\end{array}$} & 1 & Iwase Town & 100 & \multirow{4}{*}{4} & \multirow{4}{*}{ Asou } & \multirow{4}{*}{8} & \multirow{4}{*}{$\begin{array}{l}\text { Shin-Tone } \\
\text { River }\end{array}$} & 24 & Tone Town & 100 \\
\hline & & & & 2 & Yamato Village & 100 & & & & & 25 & Kawachi Town & 75 \\
\hline & & & & 3 & Makabe Town & 100 & & & & & 26 & Shin-Tone Town & 100 \\
\hline & & & & 4 & Akeno Town & 45 & & & & & 27 & Azuma Town & 100 \\
\hline & & & & 5 & Kyowa Town & 84 & \multirow{9}{*}{5} & \multirow{9}{*}{ Kitaura (1) } & 9 & Hokota River & 28 & Asahi Village & 21 \\
\hline & & & & 6 & Shimodate City & 2 & & & \multirow{5}{*}{10} & \multirow{5}{*}{ Tomoe River } & 29 & Iwama Town & 20 \\
\hline & & & & 7 & Shimotsuma City & 1 & & & & & 30 & Minori Town & 100 \\
\hline & & & & 8 & Tsukuba City & 45 & & & & & 31 & Ibaraki Town & 7.6 \\
\hline & & & & 9 & Niihari Village & 100 & & & & & 32 & Ogawa Town & 100 \\
\hline & & & & 10 & Tsuchiura City & 100 & & & & & 33 & Hokota Town & 93 \\
\hline & & 2 & Seimei River & 11 & Miho Village & 100 & & & \multirow[t]{2}{*}{11} & \multirow{2}{*}{$\begin{array}{l}\text { Yamada } \\
\text { River }\end{array}$} & \multirow[t]{2}{*}{34} & \multirow[t]{2}{*}{ Kitaura Town } & 100 \\
\hline \multirow{4}{*}{2} & \multirow{4}{*}{$\begin{array}{l}\text { Coast of } \\
\text { Takasaki }\end{array}$} & 3 & Koise River & 12 & Chiyoda Town & 100 & & & & & & & \\
\hline & & \multirow{3}{*}{4} & \multirow{3}{*}{ Sonobe River } & 13 & Yasato Town & 100 & & & 12 & $\begin{array}{c}\text { (Direct } \\
\text { Discharge) }\end{array}$ & 35 & Taiyo Village & 55 \\
\hline & & & & 14 & Ishioka City & 100 & \multirow{3}{*}{6} & \multirow{3}{*}{ Kitaura (2) } & 13 & Gantsu River & 36 & Asou Town & 100 \\
\hline & & & & 15 & Tamari Village & 100 & & & 14 & (Direct & 37 & Kashima City & 52 \\
\hline & & 5 & Kajinashi River & 16 & Tamatsukuri Town & 100 & & & & Discharge) & & & \\
\hline & & & & 17 & Kukizaki Town & 2 & & & 15 & $\begin{array}{l}\text { Yogoshi } \\
\text { River }\end{array}$ & 38 & Ushibori Town & 100.0 \\
\hline & & & & 18 & Ushiku City & 84 & 7 & Sotona- & 16 & Maekawa & 39 & Itako Town & 1000 \\
\hline & & & & 19 & Ryugasaki City & 87 & 1 & Sakaura & & Kive & 39 & & \\
\hline 3 & Center of & 6 & Ono River & 20 & Ami Town & 100 & & & 17 & Hitachi- & 40 & Hasaki Town & 100.0 \\
\hline & & & & 21 & Edosaki Town & 100 & & & & Tone River & 41 & Kamisu Town & 62.0 \\
\hline & & & & 22 & Sakuragawa Village & 100 & & & & & & & \\
\hline & & 7 & Ichinose River & 23 & Kasumigaura Town & 100 & & & & & & & \\
\hline
\end{tabular}

Table 2. Classification of Household Wastewater Disposal

\begin{tabular}{|c|l|}
\hline Index & \multicolumn{1}{|c|}{ Facility } \\
\hline 1 & Sewage System \\
\hline 2 & Rural Community Sewage System \\
\hline 3 & Combined Treatment Septic Tank \\
\hline 4 & Treatment Septic Tank \\
\hline 5 & Night Soil Septic Tank \\
\hline 6 & Untreated Domestic Wastewater \\
\hline 7 & New Type of Septic Tank A \\
\hline 8 & New Type of Septic Tank B \\
\hline
\end{tabular}

the load of total water pollutants is restricted gradually and clarifies endogenously an optimal hybrid of environmental and economic policies, namely how to control the timing and regions of economic activities and how to spend the environmental budget for the implementation of the policies. The composition of the sub-models is shown in Fig. 2. The framework of the socio- 
Table 3. Classification of Land Use

\begin{tabular}{|c|l|}
\hline Index & \multicolumn{1}{|c|}{ Land Use } \\
\hline 1 & Paddy Field \\
\hline 2 & Rice Field \\
\hline 3 & Mountain Forest \\
\hline 4 & City Area \\
\hline 5 & Other Land Use \\
\hline
\end{tabular}

Table 4. Classification of Industry

\begin{tabular}{|c|l|}
\hline Index & \multicolumn{1}{|c|}{ Industry } \\
\hline 1 & Upland Cropping \\
\hline 2 & Rice Cropping \\
\hline 3 & Dairy Farming \\
\hline 4 & Pig Farming \\
\hline 5 & Fisheries \\
\hline 6 & Manufacturing Industry \\
\hline 7 & Other Industries \\
\hline
\end{tabular}

Table 5. Measures for Tratment of Water Pollutants

\begin{tabular}{|c|c|c|}
\hline $\begin{array}{l}\text { Source of water } \\
\text { pollutants }\end{array}$ & Name of policy & Treatment Measurements \\
\hline Household & $\begin{array}{l}\text { High-grade treatment } \\
\text { and Direct reduction }\end{array}$ & $\begin{array}{l}\text { I. Subsidization for the Municipalities to install a sew- } \\
\text { age system and rural community sewage system } \\
\text { II. Subsidization for the Municipalities to promote } \\
\text { installation of a combined treatment septic tank } \\
\text { III. Subsidization for the Municipalities to promote } \\
\text { installation of a facility of new technology that substi- } \\
\text { tutes a septic tank } \\
\text { IV. Subsidization for the Municipalities to promote } \\
\text { installation of a supplementary facility of new technol- } \\
\text { ogy for the existing septic tank } \\
\text { V. Installation of a new plant that further reduces water } \\
\text { pollutants from the treated water discharged from the } \\
\text { existing sewage treatment plant }\end{array}$ \\
\hline Non-point & $\begin{array}{l}\text { Agriculture that } \\
\text { preserves } \\
\text { the environment } \\
\text { and fallow field }\end{array}$ & $\begin{array}{l}\text { VI. Subsidization for purchase of a machine to plant rice } \\
\text { seedlings with a function of precise fertilization } \\
\text { (Subsidizing rate is } 5.6 \% \text { to the purchase price*) } \\
\text { VII. Subsidy for rice farmer who uses less-elution type } \\
\text { of fertilizer } \\
\text { (Subsidization rate is } 15 \% \text { of the price**) } \\
\text { VIII. Subsidy to promote leaving field fallow (conver- } \\
\text { sion of paddy field and rice field into fallow field) }\end{array}$ \\
\hline Production & $\begin{array}{l}\text { End of pipe policy } \\
\text { and reduction } \\
\text { of the capital employed }\end{array}$ & $\begin{array}{l}\text { IX. Installation of a new technology for direct reduction } \\
\text { of water pollutants at the end of pipe at the factory } \\
\mathrm{X} \text {. Subsidy for industries to reduce working capital so as } \\
\text { to adjust production }\end{array}$ \\
\hline $\begin{array}{l}\text { Sediments at the } \\
\text { bottom and } \\
\text { dissolution }\end{array}$ & Direct reduction & $\begin{array}{l}\text { XI. Installation of facility that directly reduces water } \\
\text { pollutants discharged to Lake and rivers }\end{array}$ \\
\hline
\end{tabular}

* actual subsidizing rate of Ibaraki Prefecture

** $15 \%$ assumed based on difference in the prices

economic model, the material flow barance model and the water cycle model are shown in Figs. 3 , 4 and 5. We set some simulations so that the amount of water pollutants flowing into Kasumigaura were reduced by $\mathrm{n} \%$ by the year 2003 as compared to the actual data of 1999. For example, when the reduction rate was $20 \%$, we set the name as Case 20 . The restricted amounts of water pollutants inflow in each simulation are shown in Table 6. 


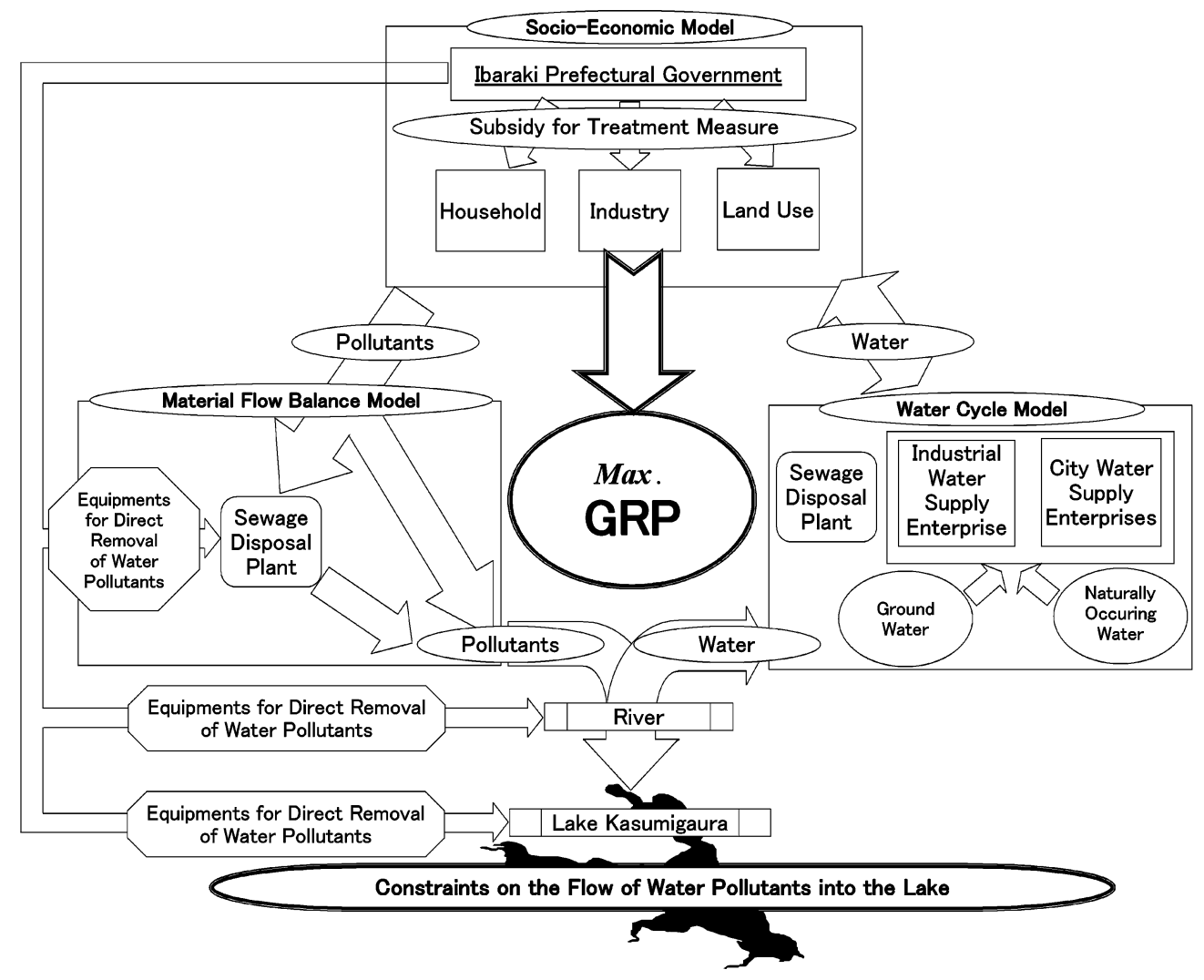

Fig. 2 Composition of the sub-models

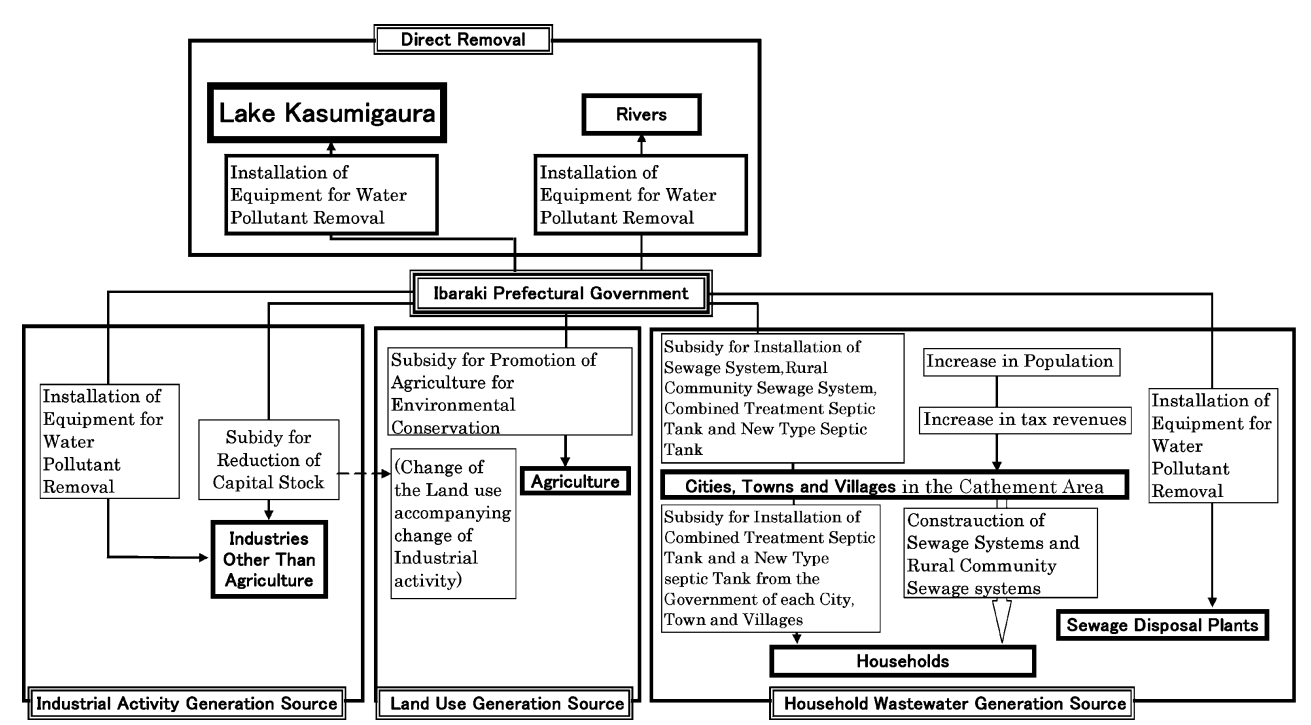

Fig. 3 Flamework of the socio-economic model 


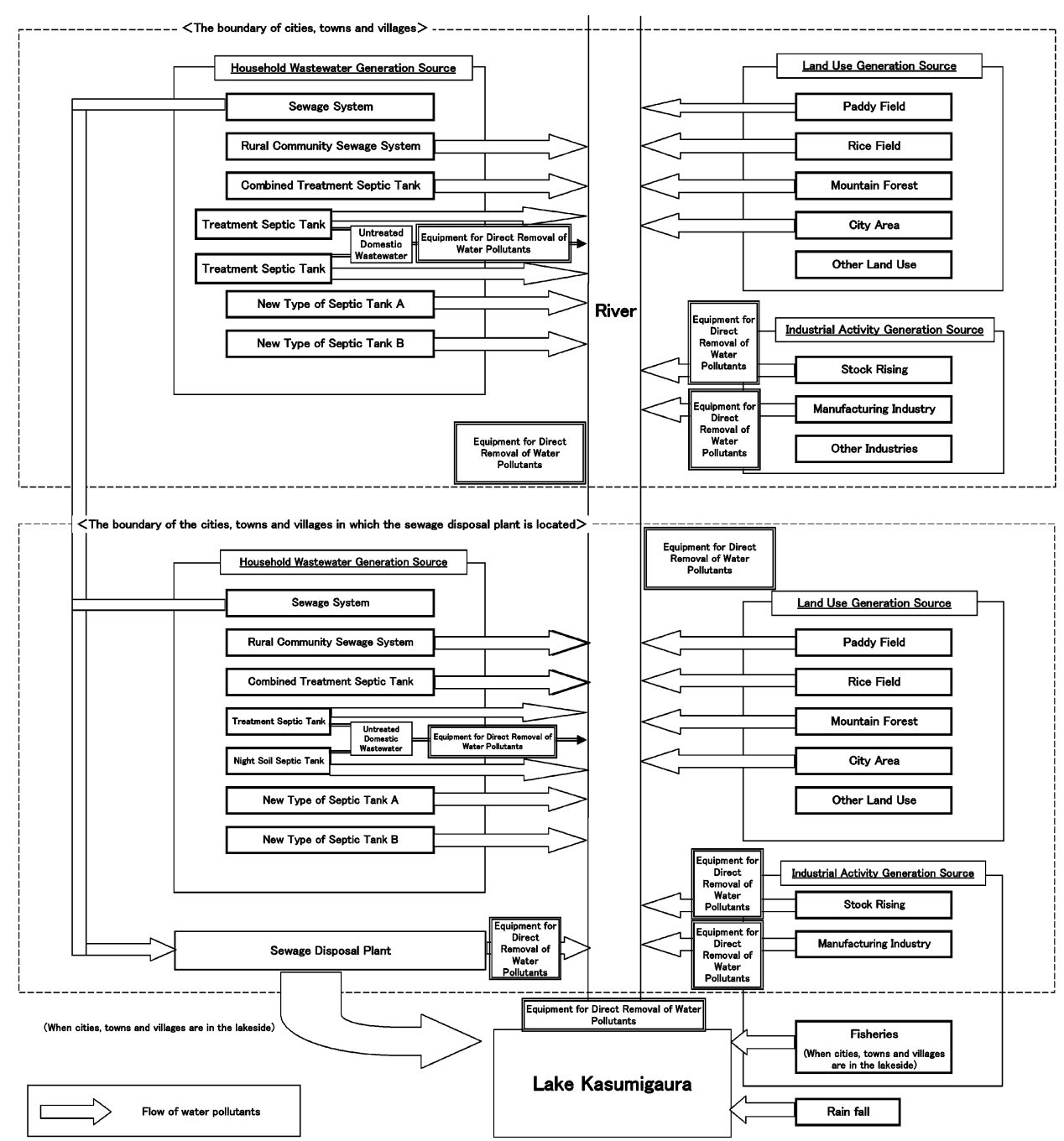

Fig. 4 The flamework of the material flow balance model

\subsection{The Model Structure}

This simulation model consists of more than ninety equations. Because of restrictions on the number of pages, only the most important model equations are presented in this paper. Please see Mizunoya [7] for more detail.

\subsubsection{Objective Function}

The market mechanism and driving force of the economy is simulated by the non-linear maximization of the gross regional products in the basin being subject to the structural constraints of socio-economic activities, the emission and the transportation of water pollutants, the water demand and supply and its recycling in the basin, the upper and lower constraints of the water level in the Lake, etc. : 


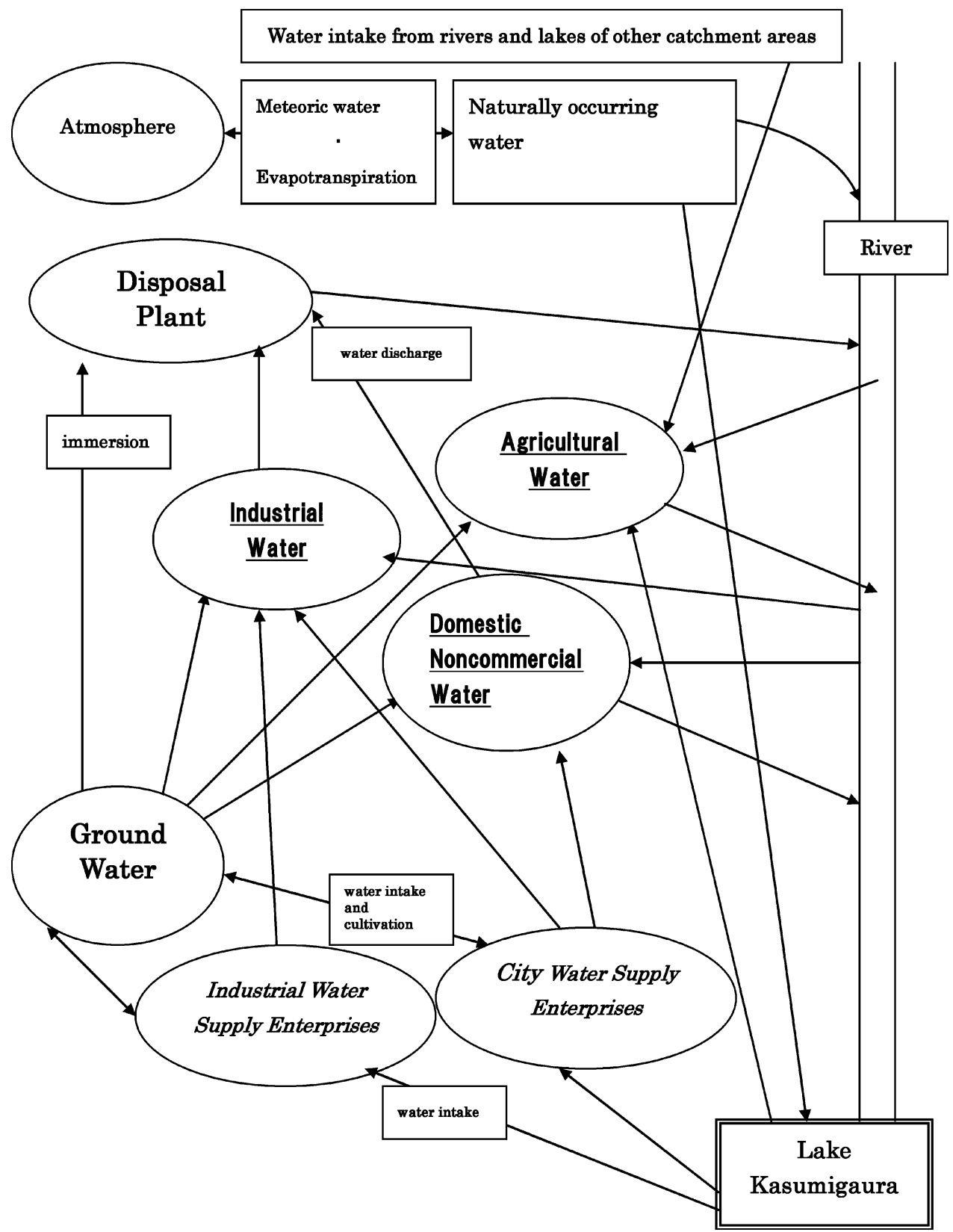

Fig. 5 Flamework of the water cycle model 
Table 6. Simulation Cases

\begin{tabular}{|c|c|c|c|c|}
\hline $\begin{array}{l}\text { Case } \\
\text { Name }\end{array}$ & $\begin{array}{l}\text { Reduction Rate in } \\
2003 \text { (compares to } \\
\text { the real data in) }\end{array}$ & $\begin{array}{l}\text { Upper Constraints } \\
\text { on the Amount of } \\
\mathrm{T}-\mathrm{N} \text { Flowing in }\end{array}$ & $\begin{array}{l}\text { Upper Constraints } \\
\text { on the Amount of } \\
\text { T-P Flowing in }\end{array}$ & $\begin{array}{l}\text { Upper Constraints } \\
\text { on the Amount of } \\
\text { COD Flowing in }\end{array}$ \\
\hline Case -0 & $0 \%$ & 4,427 & 278 & 10,532 \\
\hline Case-5 & $5 \%$ & 4,205 & 264 & 10,005 \\
\hline Case-10 & $10 \%$ & 3,984 & 251 & 9,478 \\
\hline Case-15 & $15 \%$ & 3,763 & 237 & 8,952 \\
\hline Case-20 & $20 \%$ & 3,541 & 223 & 8,425 \\
\hline Case-25 & $25 \%$ & 3,320 & 209 & 7,899 \\
\hline Case-26 & $26 \%$ & 3,276 & 206 & 7,793 \\
\hline Case-27 & $27 \%$ & 3,231 & 203 & 7,688 \\
\hline Case-28 & $28 \%$ & 3,187 & 200 & 7,583 \\
\hline Case-29 & $29 \%$ & 3,143 & 198 & 7,477 \\
\hline Case-30 & $30 \%$ & 3,099 & 195 & 7,372 \\
\hline Case-31 & $31 \%$ & 3,054 & 192 & 7,267 \\
\hline Case-32 & $32 \%$ & 3,010 & 189 & 7,162 \\
\hline Case-33 & $33 \%$ & 2,966 & 186 & 7,056 \\
\hline Case-34 & $34 \%$ & 2,922 & 184 & 6,951 \\
\hline Case-35 & $35 \%$ & 2,877 & 181 & 6,846 \\
\hline Case-36 & $36 \%$ & 2,833 & 178 & 6,740 \\
\hline Case-37 & $37 \%$ & 2,789 & 175 & 6,635 \\
\hline Case-38 & $38 \%$ & 2,744 & 173 & 6,530 \\
\hline Case-39 & $39 \%$ & 2,700 & 170 & 6,424 \\
\hline
\end{tabular}

$$
\max \sum_{t=1} \frac{1}{(1+\rho)^{(t-1)}} G R P(t)
$$

in which, $t=1: 1999, \ldots \ldots, t=5: 2003, \rho:$ social discount rate $(=0.05)$

\subsubsection{The Material Flow Balance Model}

The net water pollutants in the Lake are defined as the sum of those that flow through the rivers, are discharged by the sewage plants, fisheries and rainfall on the surface of the Lake minus direct removal from the Lake for the new technology plants. In this model, we assume no removal for water utilization from the Lake.

(1) Water pollutant load of Lake Kasumigaura

$$
Q^{h p}(t)=\sum_{i} R Q_{i}^{h p}(t)+Q F^{h p}(t)+\sum_{d} Q D_{d}^{h p}(t)+Q R^{h p}(t)-Q A L_{a}^{h p}(t),
$$

$Q^{h p}(t)$ : the total net load of pollutant $p$ in block $h$ of the Lake at time $t(e n$.$) ;$

$R Q_{i}^{h p}$ : load of pollutant $p$ in block $h$ of the river i at time $t$ (en.);

$Q F^{h p}(t)$ : load of pollutant $p$ by fisheries in block $h$ at time $t(e n$.$) ;$

$Q D_{d}^{h p}(t)$ : load of pollutant $p$ in block $h$ by sewage plant $d$ at time $t(e n$.$) ;$ 
$Q R^{h p}(t)$ : load of pollutant $p$ by rainfall in block $h$ at time $t(e x$.$) ;$

$Q A L_{a}^{h p}(t)$ : direct removal of pollutant $p$ by the plant of new technology $A$ installed in block $h$ at time $t(e n$.$) .$

*(en.) indicates endogenous variable and (ex.) indicates exogenous variable in the following equations

(2) Pollutant load in each municipality in the sub-basin of each river

Water pollutants are assumed to be generated by socio-economic activities and flow into the lake through the rivers:

$$
R Q M_{i j+1}^{h p}(t)=R Q M_{i j}^{h p}(t)+\gamma_{i j}^{h p}(t)+Q R_{i j}^{h p}(t)+Q D_{d}^{i j p}(t)-Q A R_{i j a}^{h p}(t) \quad\left(1 \leq j \leq E^{i}-1\right)
$$

$E^{i}$ : index of municipality in which the mouth of river $i$ is located;

$R Q M_{i j}^{h p}(t)$ : pollutant $p$ transported to municipality $j$ from the upstream of river $i$ that flows into block $h$ of the lake at time $t(e n$.);

$\gamma_{i j}^{h p}(t)$ : pollutant $p$ emitted by socio-economic activities in municipality $j$ in the sub-basin of river $i$ that flows in block $h(e n$.$) ;$

$Q R_{i j}^{h p}(t)$ : pollutant $p$ of the rainfall in municipality $j$ in the sub-basin of river $i$ that flows into block $h(e x$.$) ;$

$Q D_{d}^{i j p}(t)$ : pollutant $p$ discharged by the sewage plant $d$ in municipality $j$ of the sub-basin of river $i(e n$.$) ;$

$Q A R_{i j a}^{h p}(t)$ : pollutant $p$ removed by the plant of new technology $A$ installed in municipality $j$ the river $i$ that flows into block $h(e n$.).

(3) Pollutants emitted by socio-economic activities

The total pollutants emitted by socio-economic activities in the sub-basin are composed of pollutants from households, non-point sources and point sources. Pollutants caused by fisheries (mainly cultivation of carp and eel) are specified in other equations because they are directly loaded into the lake. Also, pollutants discharged through sewage are specified in other equations.

$$
r_{i j}^{h p}(t)=Q Z_{i j}^{h p}(t)+Q L_{i j}^{h p}(t)+Q X_{i j}^{h p}(t) \quad\left(1 \leq j \leq E^{i}\right),
$$

$Q Z_{i j}^{h p}(t)$ : pollutant $p$ (excluding those through sewage) loaded by households in municipality $j$ of river $i$ that flows into block $h$ at time $t(e n$.$) ;$

$Q L_{i j}^{h p}(t)$ : pollutant $p$ emitted by non-point sources in municipality $j$ of river $i$ that flows into block $h(e n$.$) ;$

$Q X_{i j}^{h p}(t)$ : pollutant $p$ emitted by socio-economic activities (excluding those by fisheries) in municipality $j$ of river $i$ that flows into block $h(e n$.).

(4) Pollutants from household wastewater in each municipality

$$
Q Z_{i j}^{h p}(t)=\sum_{k \neq 1} E^{p k} \cdot Z_{i j}^{k}(t)-\sum_{b} S A_{b}^{p} \cdot Z Z_{i j b}(t)-Q A Z_{i j a}^{p 6},
$$

$E^{p k}$ : emission coefficient of pollutant $p$ from household wastewater treatment facility $k(k \neq 1)$ $(e x$.$) ;$

$Z_{i j}^{k}(t)$ : population that used household wastewater treatment facility $k$ in municipality $j$ and discharged pollutants into river $i(e n$.$) ;$

$S A_{b}^{p}$ : removal coefficient of pollutant $p$ by new technology $b$ installed in household wastewater treatment facility ; $(e x$. $)$

$Z Z_{i j b}(t)$ : population in municipality $j$ that used household wastewater treatment facility in which new technology $b$ was installed and discharged pollutants into river $i(e n$.) ; 
$Q A Z_{i j a}^{p 6}$ : direct removal of pollutant $p$ by new technology $G$ from untreated household wastewater that was emitted in municipality $j$ and discharged into river $i(e n$.$) ;$

(5) Load of pollutants from non-point sources

$$
Q L_{i j}^{h p}(t)=G^{p l} \cdot L_{i j}^{l}(t)
$$

$G^{p l}$ : coefficient of pollutant $p$ emitted through land use $l(e x$.$) ;$

$L_{i j}^{l}(t)$ : area of land use $l$ in municipality $j$ that emitted pollutants into river $i(e n$.$) .$

(6) Load of pollutants from industrial activities

$$
Q X_{i j}^{h p}(t)=P^{p m} \cdot X_{i j}^{m}(t),
$$

$P^{p m}:$ coefficient of pollutant $p$ emitted by industry $m(e x$.$) ;$

$X_{i j}^{m}(t)$ : production of industry $m$ in the area of municipality $j$ that emitted pollutants into river $i$ (en.) ;

(7) Pollutants discharged from sewage plant

Wastewater that uses sewage services is treated at a sewage plant. It can be treated by a plant that is with high grade facility of new technology additionally installed as well as by a usual plant, namely a plant that mainly focuses on removal of organic materials such as in terms of COD/BOD. The treated wastewater is discharged into rivers in the basin, directly into the lake or discharged outside the basin (into the Tone River, etc.).

$$
\begin{gathered}
Q D_{d}^{h p}(t)=D_{d}^{h p} \sum_{j} Z_{d j}^{h 1}-\sum_{a} Q A D_{a d}^{h p}(t), \\
Q D_{d}^{i E \phi}(t)=D_{d}^{i E D} \sum_{j} Z_{d j}^{i E 1}-\sum_{a} Q A D_{a d}^{i E p}(t), \\
Q D_{d}^{i j p}(t)=D_{d}^{i j p} Z_{d j}^{i 1}-\sum_{a} Q A D_{a d}^{i j p}(t),
\end{gathered}
$$

$D_{d}^{h p}$ : coefficient of pollutant $p$ in the treated water of sewage plant $d$ directly discharged into block $h(e x$.$) ;$

$Z_{d j}^{h 1}$ : population in municipality $j$ that used sewage service (superscript index $=1$ ) of plant $d$ which discharged the treated water into block $h(e n$.$) ;$

$Q A D_{a d}^{h p}(t)$ : removal of pollutant $p$ by additional facilies of new technology $A$ installed in sewage plant $d$ that directly dischargd treated wastewater into block $h(e n$.$) ;$

$D_{d}^{i E D}(t)$ : coefficient of pollutant $p$ in the treated wastewater of sewage plant $d$ that is directly discharged into the mouth of river $i$ at municipality $E(e x$.$) ;$

$Z_{d j}^{i E 1}$ : population in municipality $j$ that used the sewage service (superscript index $=1$ ) of plant $d$ to directly discharge treated wastewater into the mouth of river $i$ at municipality $E(e n$.) ; $Q A D_{a d}^{i E D}(t)$ : removal of pollutant $p$ by the facility with new technology A installed in sewage plant $d$ that discharged the treated wastewater into the mouth of river $i$ at municipality $E(e n$.$) ;$

$D_{d}^{i j p}(t)$ : coefficient of pollutant $p$ for the treated wastewater of sewage plant $d$ at municipality $j$ that was discharged into river $i(e x$.$) ;$

$Z_{d j}^{i 1}$ : population in municipality $j$ that used the sewage service (superscript index $=1$ ) of plant $d$ to discharge treated wastewater into river $i(e n$.$) ;$

$Q A D_{a d}^{i j p}(t)$ : removal of pollutant $p$ by the facility of new technology $A$ installed in the sewage plant $d$ at municipality $j$ to discharge treated wastewater into river $i(e n$.$) ;$

(8) Direct removal of pollutants by new technology

The direct removal of pollutants are dependent on the number of facilities of new technology 
(capital stock) and the direct removal coefficient of the facilies.

$$
\begin{gathered}
Q A L_{a}^{h p}=A_{a}^{p} \cdot K A_{a}^{h}, \\
Q A D_{a d}^{h h}(t)=A_{a}^{p} \cdot K A_{a d}^{h} \\
Q A D_{a d}^{i E p}(t)=A_{a}^{p} \cdot K A_{a d}^{i E} \\
Q A D_{a d}^{i j p}(t)=A_{a}^{p} \cdot K A_{a d}^{i j} \\
Q A R_{a d}^{h p}(t)=A_{a}^{p} \cdot K A_{i j a}^{h} \\
Q A Z_{i j a}^{p 6}(t)=A_{a}^{p} \cdot K A_{i j d}^{6}
\end{gathered}
$$

$A_{a}^{p}$ : removal coefficient of pollutant $p$ by the facility of new technology $a(e x$.$) ;$

$K A_{a}^{h}$ : the number of facilities of new technology $a$ installed in or around block $h$ of the lake (endogenous variable);

$K A_{a d}^{h}$ : the number of facilities of new technology $a$ installed in sewage pland $d$ that discharge treated wastewater into $h$ of the lake (endogenous variable);

$K A_{a d}^{i E}$ : the number of facilities of new technology $a$ installed in sewage pland $d$ that discharge treated wastewater into at the mouth of river $i$ in municipality $E$ of the lake (endogenous variable) ;

$K A_{a d}^{i j}$ : the number of facilities of new technology $a$ installed in sewage plant $d$ that discharge treated wastewater into river $i$ at municipality $j(e n$.$) ;$

$K A_{i j a}^{h}$ : the number of facilities of new technology $a$ that are installed in river $i$ flowing into block $h$ at municipality $j$ and directly remove pollutants from the river (en.);

$K A_{i j d}^{6}$ : the number of facilities of technology $G$ that are installed at municipality $j$ in the sub-basin of river $i$ and directly remove pollutants from untreated wastewater (superscript index $=6$ ) (en.).

\subsubsection{The Socio-Economic Model}

2.5.3.1 Treatment measures for household wastewater generation sources

The measures for treatment of household wastewater include provision of sewage services, rural community sewage services, installation of combined treatment septic tank, and promotion of the installation of new technologies that can be substituted for existing septic tank. These measures are mainly implemented by local governments.

(1) Budget of Municipality

It is assumed that the budget of a municipality is dependent on the size of the population:

$$
R_{i j}(t)=\rho_{i j} z_{i j}(t)
$$

$R_{i j}(t)$ : the budget of municipality $j$ for the sub-basin of river $i(e n$.$) ;$

$\rho_{i j}$ : the budget per person of municipality $j$ for the sub-basin of river $i(e x$.$) .$

(2) Equipment for sewage and rural community sewage services

An increase in the population that uses a sewage system or a rural community sewage system are dependent on the construction investment:

$$
\sum_{i \in I(j)} \Delta z_{i j}^{k}(t) \leq \Gamma_{j}^{k} \cdot i_{j}^{k}(t)
$$

$\Gamma_{j}^{k}$ : reciprocal of the necessary construction investment per person that uses the sewage and rural community sewage services $(e x$.$) .$

$i_{j}^{k}(t)$ : construction investment of municipality $j$ for sewage system $(k=1)$ and rural community sewage system $(k=2)(e n$.$) ;$ 
(3) Sewage system and rural community sewage system

The investment for construction of a sewage system and rural sewage system is determined by the construction allotment of the municipality and subsidies that are provided by the prefectural and central governments for the allotment:

$$
i_{i}^{k}(t)=\left(\frac{1}{1-M_{j}^{k}}\right) c c_{j}^{k}(t)
$$

$M_{j}^{k}$ : rate of the subsidization by the prefectural and central governments $(e x$.$) ;$

$c c_{j}^{k}(t)$ : construction allotment of municipality $j(k=1$ : sewage system ; $k=2$ : rural community sewage system) (en.).

(4) Construction allotment of municipality for sewage system

The construction allotment of municipality is covered by transfer from the general account and local bond :

$$
c c_{j}^{k}(t)=d b_{j}^{k}(t)+b_{j}^{k}(t)
$$

$d b_{j}^{k}(t)$ : amount of the local bonds issued by the municipality $j \quad(k=1:$ sewage system ; $k=2:$ rural community sewage system) (en.) ;

$b_{j}^{k}(t)$ : amount transferred from the general account of municipality $j(e n$.$) .$

(5) Maintenance costs of the sewage system

Maintenance costs of the sewage system and rural community sewage system are covered by the users and municipality :

$$
m c_{j}^{k}(t)=\nu_{j}^{k} z_{i j}^{k}(t)=N_{j}^{k} z_{i j}^{k}(t)+g_{j}^{k}(t),
$$

$m c_{j}^{k}(t)$ : total maintenance cost of facility $k \quad(k=1$ : sewage system ; $k=2$ : rural community sewage system) in municipality $k(e n$.$) ;$

$\nu_{j}^{k}$ : maintenance cost per user of $k$ in $j(e x$.$) ;$

$N_{j}^{k}$ : user charge per person of $k$ in $j(e x$.$) ;$

$g_{j}^{k}(t)$ : transfer from the general account of $j$ to cover maintenance costs of $k(e x$.$) .$

(6) Subsidization for installation of combined treatment septic tank

The installation of a combined treatment septic tank $(k=3)$ is subsidized by the municipality, the central government and the prefectural government:

$$
\delta \Delta z_{i j}^{3}(t)=\frac{1}{1-M^{3}} b_{j}^{3}(t)
$$

$\delta$ : installation cost of combined treatment septic tank per person (ex.) ;

$M^{3}$ : rate of subsidization by the central and prefectural governments (ex.) ;

$b_{j}^{3}(t)$ : amount of transfer from the general account of municipality $j$ for the installation of a combined treatment septic tank (en.).

(7) Subsidization for facility of new technology substitutable for septic tank

The installation of a facility of new technology that can be substituted for a septic tank is subsidized by the municipality and the prefectural government:

$$
\mu^{k} \Delta z_{j}^{k}(t)=\left(\frac{1}{1-M^{k}}\right) b_{j}^{k}(t)
$$

$\mu^{k}$ : installation costs of facility $k(k=7$ : new technology $A: k=8: B)$ per person (ex.); $M^{k}$ : rate of subsidization by the prefectural government (ex.) 
$b_{j}^{k}(t)$ : amount transferred from the general account of municipality $j$ for the installation of $k(e n$.$) .$

(8) Budget constraints

Subsidization by the municipality for construction of a sewage system $(k=1)$ and rural community sewage system $(k=2)$, and installation of a combined treatment septic tank $(k=3)$ and the facility of new technology $A(k=7)$ and $B(k=8)$, is covered by a special account in which a specific portion of the general account of the municipality and the household wastewater treatment subsidy granted by the prefectural government to the municipality for intensive promotion of construction and installation of measures for treatment of household wastewater:

$$
b_{j}^{1}(t)+b_{j}^{2}(t)+b_{j}^{3}(t)+b_{j}^{7}(t)+b_{j}^{8}(t)+g_{j}^{1}(t)+g_{j}^{2}(t) \leq \omega_{j} R_{j}(t)+s_{j}^{1}(t),
$$

$\omega_{j}$ : transfer of the special account of measures for treatment of household wastewater to the general account of municipality $j(e x$.$) ;$

$s_{j}^{1}(t)$ : subsidy for household wastewater measures (superscript index $=1$ ) in municipality $j$ which is granted by the prefectural government to the special account of the municipality (en.) ;

\subsubsection{Treartment measures for non-point generation sources}

(1) Fallow field promotion policy

The conversion of paddy fields and rice fields to fallow fields (categorized as "other land use") is subsidized by the prefectural government :

$$
L_{j}^{l 5}(t) \geq \lambda^{l} s_{j}^{l}(t),
$$

$L_{j}^{L L}(t)$ : conversion of land use from $l$ to $L$ in municipality $j(e n$.$) ;$

$L_{j}^{L l}(t)$ : conversion of land use from $L$ to $l$ in municipality $j(e n$.$) .$

$\lambda^{l}$ : reciprocal of the subsidy for one unit conversion of land use $l$ to land use of other purposes (index =5) (ex.);

$s_{j}^{l}(t)$ : subsidy given by the prefectural government for conversion of land use $l$ ( $l=1$ : paddy field ;

$l=2$ : rice field) into land use for other purposes in municipality $j(e n)$.

\subsubsection{Treartment measures for industrial activity generation sources}

(1) Production function and curtailment

Production is dependent on the capital accumulated. The prefectural government restricts production paddy of fields $(m=1)$ and rice fields $(m=2)$ by the fallowing policy. The production of other industries $(m=3, \cdots, 8)$ is restricted by leaving capital idle and subsidizing for loss due to the idle capital. The production paddy of fields and rice fields is also dependent on the area of cultivated land.

$$
\begin{gathered}
x_{j}^{m}(t) \leq \alpha^{m} \cdot k_{j}^{m}(t) \quad \text { for } m=1 \text { and } m=2, \\
x_{j}^{m}(t) \leq \alpha^{m}\left\{k_{j}^{m}(t)-s_{j}^{m}(t)\right\} \quad \text { for } m=3, \cdots, 8,
\end{gathered}
$$

$\alpha^{m}$ : ratio of capital to output in industry $m(e x$.$) .$

$$
x_{j}^{m}(t) \leq \beta^{m} L_{j}^{l}
$$

$\beta^{m}$ : ratio of cultivated land to output in industry $m$ ( $m=1:$ paddy field ; $m=2$ : rice field) (ex.).

(2) Capital accumulation

$$
k_{j}^{m P}(t+1)=k_{j}^{m P}(t)+i_{j}^{m P}(t)-d^{m} k_{j}^{m P}(t)
$$

$k_{j}^{m P}(t)$ : capital of industry $m$ available in municipality $j$ at time $t(e n$.$) ;$ $i_{j}^{m P}(t)$ : investment for industry $m$ in municipality $j$ at time $t(e n$.) ; 
$d^{m}:$ depreciation rate of industry $m(e x$.$) .$

2.5.3.4 Budget for installation of new technology for direct removal

(1) Budget for installation and maintenance

The prefecture installs plants or facilities in the lake or in the sewage plant that directly remove water pollutants and maintains it:

$$
\begin{gathered}
S_{h}^{a}(t) \geq i_{h}^{a}(t)+m c_{h}^{a}(t), \\
S_{j}^{a}(t) \geq i_{j}^{a}(t)+m c_{j}^{a}(t), \\
S_{d}^{a}(t) \geq i_{d}^{a}(t)+m c_{d}^{a}(t), \\
S_{d}^{6 a}(t) \geq i_{j}^{6 a}(t)+m c_{j}^{6 a}(t),
\end{gathered}
$$

$S_{h}^{a}(t)$ : budget assigned to the plant for direct removal by new technology installed in block $h(e n$.$) ;$ $S_{j}^{a}(t)$ : budget assigned to the plant for direct removal by new technology installed in the river of municipality $j(e n$.$) ;$

$S_{d}^{a}(t)$ : budget assigned to the facility for direct removal by new technology installed in sewage plant $d(e n$.$) ;$

$S_{d}^{6 a}(t)$ : budget assigned to the facility for direct removal by new technology $G$ that treats nonpurified household sewage (index $=6$ ) in municipality $j(e n$.$) ;$

$i_{h}^{a}(t)$ : investment to the plant for direct removal by new technology installed in block $h(e n$.$) ;$

$i_{j}^{a}(t)$ : investment to the plant for direct removal by new technology installed in the river of municipality $j(e n$.$) ;$

$i_{d}^{a}(t)$ : investment of budget assigned to the facility for direct removal by new technology installed in sewage plant $d(e n$.$) ;$

$i_{j}^{6 a}(t)$ : investment to the facility for direct removal by new technology $G$ that treats non-purified household sewage (index $=6$ ) in municipality $j(e n$.$) ;$

$m c_{h}^{a}(t)$ : maintenance costs of the plant for direct removal by new technology installed in block $h$ $(e x$.$) ;$

$m c_{j}^{a}(t)$ : maintenance costs of the plant for direct removal by new technology installed in the river of municipality $j(e n$.$) ;$

$m c_{d}^{a}(t)$ : maintenance costs of the facility for direct removal of new technology installed in sewage plant $d(e n$.$) ;$

$m c_{j}^{6 a}(t)$ : maintenance costs of the facility for direct removal by new technology $G$ that treats nonpurified household sewage (index $=6$ ) in municipality $j(e n$.$) .$

(2) Maintenance costs of new technology for direct removal

The maintenance costs are dependent on the number of the facilities/plants installed:

$$
\begin{aligned}
m c_{h}^{a}(t) & =M^{a} \cdot K A_{h}^{a}(t), \\
m c_{j}^{a}(t) & =M^{a} \cdot K A_{j}^{a}(t), \\
m c_{d}^{a}(t) & =M^{a} \cdot K A_{d}^{a}(t), \\
m c_{j}^{6 a}(t) & =M^{a} \cdot K A_{j}^{6 a}(t),
\end{aligned}
$$

$M^{a}$ : maintenance cost per one million JPY of the facility/plant with new technology $(e x$.$) .$

(3) Accumulation of facilities/plants with new technology

$$
\begin{gathered}
K A_{h}^{a}(t+1)=K A_{h}^{a}(t)+i_{h}^{a}(t)-d^{a} K A_{h}^{a}(t), \\
K A_{j}^{a}(t+1)=K A_{j}^{a}(t)+i_{j}^{a}(t)-d^{a} K A_{j}^{a}(t), \\
K A_{d}^{a}(t+1)=K A_{d}^{a}(t)+i_{d}^{a}(t)-d^{a} K A_{d}^{a}(t), \\
K A_{j}^{6 a}(t+1)=K A_{j}^{6 a}(t)+i_{j}^{6 a}(t)-d^{G} K A_{j}^{6 a}(t),
\end{gathered}
$$


$d^{a}$ : depreciation rate of facility/plant with new technology (ex.);

$d^{G}$ : depreciation rate of facility/plant with new technology $G(e x$.$) .$

(4) Budget for new technology that supplements septic tank

The Prefecture subsidizes municipalities to cover all the necessary costs of installation and maintenance of new technology that supplements septic tanks:

$$
\begin{gathered}
S_{j}^{b}(t) \geq i_{j}^{b}(t)+m c_{j}^{b}(t), \\
i_{j}^{b}(t)=\theta^{b} \cdot \Delta Z Z_{j}^{b}(t), \\
m c_{j}^{b}(t)=M^{b} \cdot Z Z_{j}(t), \\
Z Z_{j}^{b}(t+1)=Z Z_{j}^{b}(t)+\Delta Z Z_{j}^{b}(t), \\
Z Z_{j}^{b}(t) \leq Z_{j}^{3}(t),
\end{gathered}
$$

$S_{j}^{b}(t)$ : budget assigned to municipality $j$ for installation and maintenance of the facility for new technology that supplements a septic tank (en.);

$i_{j}^{b}(t)$ : installation cost of the facility for new technology that supplements a septic tank in municipality $j(e n$.$) ;$

$m c_{j}^{b}(t)$ : maintenance cost of the facility for new technology that supplements a septic tank in municipality $j(e n$.)

$\theta^{b}$ : installation cost per person of the facility for new technology that supplements a septic tank (ex.);

$\Delta Z Z_{j}^{b}(t)$ : change in population of municipality $j$ that use the facility with new technology that supplements septic tank (en.) ;

$M^{b}$ : maintenance costs per person for the facility with new technology that supplements a septic tank (ex.) ;

$Z Z_{j}(t)$ : population in municipality $j$ that use the facility with new technology that supplements septic tank (en.).

\subsubsection{Total budget of the Prefecture for the countermeasures}

It is assumed that the prefectural government spends 20 billion JPY for implementing the countermeasures every year. This figure is based on the actual budget that has been directly and indirectly spent to improve the quality of the lake in the past:

$$
\begin{aligned}
y(t) \geq & \sum_{j} S_{j}^{1}(t)+\sum_{j} \sum_{m} S_{j}^{m}(t)+\sum_{j} \sum_{l} S_{j}^{l}(t)+\sum_{a} \sum_{h} S_{h}^{a}(t)+\sum_{a} \sum_{j} S_{j}^{a}(t)+\sum_{a} \sum_{d} S_{d}^{a}(t) \\
& +\sum_{b} \sum_{j} S_{j}^{b}(t)+\sum_{a} \sum_{j} S_{j}^{6 a}(t)+\sum_{j} S S_{j}(t)+\sum_{j} S U_{j}(t),
\end{aligned}
$$

$y(t)$ : the total budget spent by the prefectural government for implementing the countermeasures $(e x$.$) .$

2.5.3.6 Flow balance in the commodity market

Total products of each industry are decided by balances between supply and demand.

$$
\begin{aligned}
\boldsymbol{x}(t) \geq & \boldsymbol{A} \boldsymbol{x}(t)+\boldsymbol{C}(t)+\boldsymbol{i}^{P}(t)+\boldsymbol{B}^{S}\left(i^{1}(t)+i^{2}(t)\right) \\
& +\boldsymbol{B}^{c}\left(\delta \Delta Z^{3}(t)\right)+\sum_{k} \boldsymbol{B}^{k}\left(\delta^{K} \Delta Z^{k}(t)\right) \\
& +\sum_{a} \boldsymbol{B}^{a} \cdot i^{a}(t)+\sum_{b} B^{b}\left(\theta^{b} \Delta Z Z^{b}(t)\right)+\boldsymbol{e}(t),
\end{aligned}
$$

$\boldsymbol{x}(t)=\sum_{j} \boldsymbol{x}_{j}(t)$ : column vector of the $m t h$ element is the total product of industry $m$ in the basin (en.);

$\boldsymbol{i}^{P}(t)=\sum_{j} i_{j}^{P}(t):$ column vector of the $m$ th element is the total investment in industry $m(e n$.$) ;$

$i^{h}(t)=\sum_{i} i_{i}^{h}(t)$ : total investment for construction of sewage system $(k=1)$ and rural community 
sewage $(k=2)(e n$.$) ;$

$\delta \Delta z^{3}(t)=\delta \sum_{i} \Delta z_{i}^{3}(t)$ : total investment for installation of a combined treatment septic tank (superscript index $=3)($ en. $)$;

$\delta^{k} \Delta z^{k}(t)=\delta^{k} \sum_{i} \Delta z_{i}^{k}(t)$ : total investment for the installation of new technology that is substitutable for a septic tank $(k=7,8)$ (en.);

$\boldsymbol{A}$ : input-output coefficient matrix (ex.);

$\boldsymbol{C}(t)$ : column vector of consumption (en.);

$\boldsymbol{B}^{s}$ : column vector of the $i^{\text {th }}$ coefficient is induced production in industry $i$ by construction of sewage and rural community sewage systems (ex.);

$\boldsymbol{B}^{c}$ : column vector of the $i^{\text {th }}$ coefficient is induced production in industry $i$ by construction of a combined treatment septic tank (ex.) ;

$\boldsymbol{B}^{k}$ : column vector of the $i^{\text {th }}$ coefficient is induced production in industry $i$ by construction of a facility that is substitutable for septic tank $(k=7,8) \quad($ ex. $)$;

$\boldsymbol{B}^{a}$ : column vector of the $i^{\text {th }}$ coefficient is induced production in industry $i$ by construction of a facility/plant for direct removal of pollutants $(e x$.$) ;$

$i^{a}(t)=\sum_{h} i_{h}^{a}(t)+\sum_{j} i_{j}^{a}(t)+\sum_{d} i_{d}^{a}(t)$ : total investment for construction of a facility/plant for direct removal of pollutants (en.);

$\boldsymbol{e}(t)$ : column vector of net export (en.).

\subsubsection{Gross Regional Product}

We consider the gross regional product of the basin as an index that reflects the level of all socio-economic activities. It is also a potential function in which maximization of the function simulates the driving force of the economy and market mechanism.

$$
G R P(t)=\boldsymbol{v} \boldsymbol{x}(t),
$$

$v$ : row vector of $i^{\text {th }}$ element is rate of added value in the $i^{\text {th }}$ industry $(e x$.$) .$

\subsubsection{The Water Cycle Model}

The water cycle model of the basin was largely created on the basis of the studies by Aramaki and Matsuo [1], Aramaki and Matsuo [2].

Water in the lake and rivers are utilized for agriculture, manufacturing and tap water. An optimal amount of water taken from the rivers, lake and drainage are controlled so that running water from the rivers and the water level of the lake are stable within a specific range of the simulation.

(1) River flow in the municipality

$$
\begin{aligned}
R_{j+1}^{h i}(t)= & R_{j}^{h i}(t)+\left\{S F_{j}^{i}(t)-U D S_{j}^{i}(t)-U I S_{j}^{i}(t)-U A S_{j}^{i}(t)\right\} \\
& +\left\{U D_{j}^{s}(t)-L U D_{j} \cdot U D_{j}^{s}(t)-\sum_{d} S P U D_{j d}^{i}(t)\right\} \\
& +\left\{U I_{j}^{s}(t)-L U I_{j} \cdot U I_{j}^{s}(t)-\sum_{d} S P U I_{j d}^{i}(t)\right\} \\
& +\left(1-L U A_{j}\right) \cdot U A_{j}^{s}(t) \\
& +\sum_{d}\left\{S P W_{j d}^{i} \cdot S P_{d}(t)\right\}
\end{aligned}
$$

$R_{j}^{h i}(t)$ : river flow in municipality $j$ along river $i$ that flows into block $h$ at time $t(e n$.)

$S F_{j}^{i}(t)$ : spontaneous generation flow rate in municipality $j$ along river $i(e n$.)

$U D S_{j}^{i}(t)$ : amount of city water taken by residents in municipality $j$ from river $i(e n$.

$U I S_{j}^{i}(t)$ : amount of industrial water taken from river $i$ for usage in municipality (en.)

$U A S_{j}^{i}(t)$ : amount of agricultural water taken from river $i$ of municipality $j(e n$.) 
$U D_{j}^{s}(t)$ : total supply of city water for municipality $i(e n$.

$L U D_{j}$ : loss of water used for household activity in municipality $i(e x$.

$S P U D_{j d}^{i}(t)$ : household wastewater flow from municipality $j$ to sewage plant $d(e n$.)

$U I_{j}^{s}(t)$ : total supply of industrial water for municipality $j(e n$.

$L U I_{j}:$ loss of water used for industrial activity in municipality $i(e x$.

$\operatorname{SPUI} i_{j d}^{i}(t)$ : industrial waste water flow from municipality $j$ to sewage plant $d(e n$.)

$L U A_{j}$ : loss of water used for agricultural activity in municipality $i(e x$. $)$

$U A_{j}^{s}(t)$ : total supply of agricultural water in municipality $j(e n$.

$S P W_{j d}^{i}$ : coefficient that shows the release of treated water from the sewage plant into river $i$ from municipality $j$ (released $=1$, not released $=0)(e x$.

$S P_{d}(t)$ : total amount of wastewater treated in sewage plant $d(e n$.

\subsubsection{Constraints on Each Pollutant}

We set constraints on the amount of T-N, T-P and COD flow into Lake Kasumigaura for each year.

$$
Q^{P *}(t) \geq \sum_{h} Q^{h p}(t)
$$

$Q^{P *}(t)$ : restrictions on flow of each water pollutant into Lake Kasumigaura (ex.)

\subsubsection{Water Quality}

In this model, the water quality of each flowing river was determined by the follwing equation.

$$
W Q_{i j}^{h p}(t)=\frac{R Q M_{i j}^{h p}(t)}{R_{j}^{h i}(t)}
$$

$W Q_{i j}^{h p}(t)$ : water quality of river $i$ flowing along municipality $j$

\section{About the new technology to improve water quality}

Recently, research on developing water pollutant removal equipment and inventing discharge control technology to improve water quality are being carried out. In this research, we dealt with twelve types of new technologies that were improved in the Project for Water Environment Renovation of Lake Kasumigaura. We classified the new technologies into three categories as follows. The numerical data of each new technology are shown in the Appendix.

\section{Result of the simulation}

\subsection{Objective Function}

The changes in the objective values (total GRP) of two different cases: "new technologies were introduced" and "were not introduced" are shown in Figure 6.

In this simulation, a feasible solution was achieved from Case 0 to Case 39, when we adopted introduction of the new technologies policy. On the other hand, when we did not adopt the policy, a feasible solution was reached from Case 0 to Case 33. Comparing the results of these simulations, the introduction of new technologies is very effective to reduce the water pollutants.In the simula-

Table 7. Clasificasion of New Technology

\begin{tabular}{|c|l|}
\hline Category No. & \multicolumn{1}{c|}{ Category Name } \\
\hline 1 & New type of septic tank \\
\hline 2 & New type of technology installed in the existing septic tank \\
\hline 3 & Direct removal equipment \\
\hline
\end{tabular}




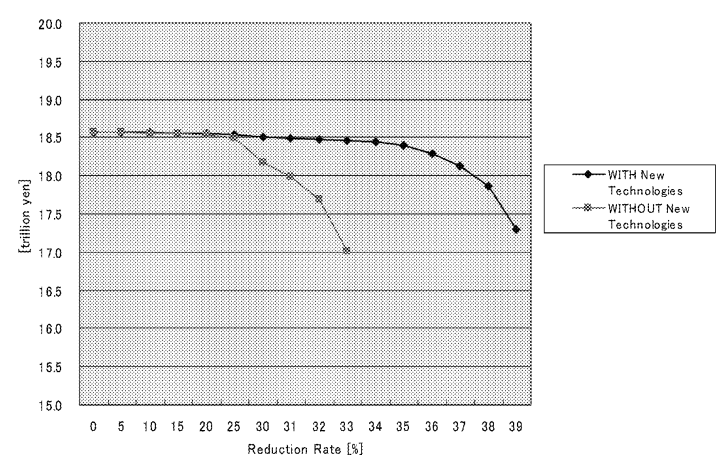

Fig. 6 The change in the objective value

Table 8. Comparing Amounts of Pollutants with Constraints (WITH New Technologies)

\begin{tabular}{|c|c|c|c|c|c|c|}
\hline \multirow{2}{*}{ Case Name } & \multicolumn{2}{|c|}{ COD } & \multicolumn{2}{c|}{ T-N } & \multicolumn{2}{c|}{ T-P } \\
\cline { 2 - 7 } & $\begin{array}{c}\text { Constraint } \\
(\mathrm{t})\end{array}$ & $\begin{array}{c}\text { Amount of } \\
\text { Pollutant } \\
\text { Derived in } \\
\text { Simulation } \\
(2003)(\mathrm{t})\end{array}$ & $\begin{array}{c}\text { Constraint } \\
(\mathrm{t})\end{array}$ & $\begin{array}{c}\text { Amount of } \\
\text { Pollutant } \\
\text { Derived in } \\
\text { Simulation } \\
(2003)(\mathrm{t})\end{array}$ & $\begin{array}{c}\text { Amount of } \\
\text { Constraint } \\
(\mathrm{t})\end{array}$ & $\begin{array}{c}\text { Pollutant } \\
\text { Derived in } \\
\text { Simulation } \\
\text { (2003) }\end{array}$ \\
\hline Case-0 & 10,532 & 10,214 & 4,427 & 4,427 & 278 & 226 \\
\hline Case-5 & 10,005 & 9,676 & 4,205 & 4,205 & 264 & 202 \\
\hline Case-10 & 9,478 & 8,369 & 3,984 & 3,984 & 251 & 164 \\
\hline Case-15 & 8,952 & 7,247 & 3,763 & 3,763 & 237 & 151 \\
\hline Case-20 & 8,425 & 7,083 & 3,541 & 3,541 & 223 & 148 \\
\hline Case-25 & 7,899 & 6,792 & 3,320 & 3,320 & 209 & 117 \\
\hline Case-30 & 7,372 & 6,291 & 3,099 & 3,099 & 195 & 98 \\
\hline Case-35 & 6,846 & 5,800 & 2,877 & 2,877 & 181 & 86 \\
\hline Case-36 & 6,740 & 5,689 & 2,833 & 2,833 & 178 & 84 \\
\hline Case-37 & 6,635 & 5,686 & 2,789 & 2,789 & 175 & 84 \\
\hline Case-38 & 6,530 & 5,609 & 2,744 & 2,744 & 173 & 84 \\
\hline Case-39 & 6,424 & 5,411 & 2,700 & 2,700 & 170 & 83 \\
\hline
\end{tabular}

tion, introduction of new technologies raised the rate of reduction level $6 \%$ as compared to no intoroduction of new technologies. Moreover, when introduction of the new technology reduced the rate by $33 \%$, the objective value had a difference of about 1.4 trillion yen as compared to no introduction of the new technology.

\subsection{The Amount of Water Pollutants Flowing into Lake Kasumigaura}

The differences in the amount of water pollutants flowing into Lake Kasumigaura derived in the simulation and the constraint amount are shown in Table 8 . In this Table, we can see the amount of inflow of $\mathrm{T}-\mathrm{N}$ is equivalent to the restrictions. On the other hand, the amount of $\mathrm{T}-\mathrm{P}$ and COD are much less than the constraint amount. This result shows that the present technology has an inadequate abatement capability for $\mathrm{T}-\mathrm{N}$ as compared with other pollutants. Also it shows 
that we should consider the reduction of $\mathrm{T}-\mathrm{N}$ as the most important subject when we formulate an environmental policy or develop new technology to improve the water quality.

\subsection{The Water Quality of Rivers Flowing into Lake Kasumigaura}

The average $\mathrm{T}-\mathrm{N}$ concentration of the inflow river in 2003 is shown in Fig. 7. It is interesting that the average concentration becomes the minimum in Case 37 and becomes larger again as reduction rate is enlarged. This is because the water cycle becomes blunt with stagnation of

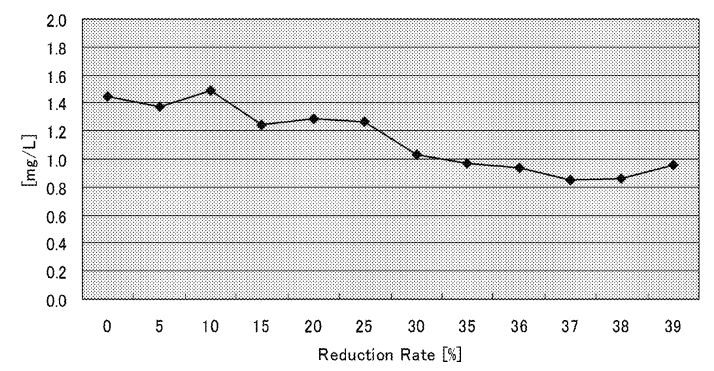

Fig. 7 Average $\mathrm{T}-\mathrm{N}$ concentration at the river mouth in 2003

Table 9. Average T-N concentration at the river mouth (Case 37) (mg/L)

\begin{tabular}{|c|c|c|c|c|c|c|c|c|c|}
\hline \multicolumn{2}{|c|}{ Water Area } & \multicolumn{2}{|r|}{ Rivers } & \multirow{2}{*}{$\begin{array}{c}1999 \\
\text { (value at the } \\
\text { observation } \\
\text { point) }\end{array}$} & \multirow[b]{2}{*}{1999} & \multirow[b]{2}{*}{2000} & \multirow[b]{2}{*}{2001} & \multirow[b]{2}{*}{2002} & \multirow[b]{2}{*}{2003} \\
\hline No. & Name & No. & Name & & & & & & \\
\hline \multirow{2}{*}{1} & \multirow{2}{*}{$\begin{array}{l}\text { Coast of } \\
\text { Tsuchiura }\end{array}$} & 1 & Sakura River & 1.8 & 0.79 & 0.68 & 0.54 & 0.61 & 0.59 \\
\hline & & 2 & Seimei River & 2.4 & 1.7 & 1.51 & 1.35 & 0.86 & 0.84 \\
\hline \multirow{3}{*}{2} & \multirow{3}{*}{$\begin{array}{l}\text { Coast of } \\
\text { Takasaki }\end{array}$} & 3 & Koise River & 3 & 2.51 & 2.52 & 2.21 & 1.96 & 1.91 \\
\hline & & 4 & Sonobe River & 5.2 & 0.81 & 0.89 & 0.99 & 1.02 & 0.91 \\
\hline & & 5 & Kajinashi River & 4.5 & 1.56 & 1.41 & 1.18 & 0.97 & 1.06 \\
\hline \multirow{2}{*}{3} & \multirow{2}{*}{$\begin{array}{l}\text { Center of } \\
\text { the Lake }\end{array}$} & 6 & Ono River & 3.1 & 1.96 & 1.69 & 1.38 & 1.07 & 1.03 \\
\hline & & 7 & Ichinose River & 4.1 & 1.68 & 1.45 & 1.54 & 1.31 & 1.3 \\
\hline 4 & Asou & 8 & Shin-Tone River & 1.6 & 0.64 & 0.53 & 0.51 & 0.51 & 0.39 \\
\hline \multirow{4}{*}{5} & \multirow{4}{*}{ Kitaura 1} & 9 & Hokota River & 6.7 & 1.9 & 1.77 & 1.86 & 1.93 & 1.5 \\
\hline & & 10 & Tomoe River & 5.1 & 0.6 & 0.54 & 0.57 & 0.45 & 0.45 \\
\hline & & 11 & Yamada River & 6 & 1.55 & 1.43 & 1.14 & 1.21 & 1.22 \\
\hline & & 12 & (Direct Discharge) & - & 1.6 & 1.58 & 1.43 & 1.29 & 1.16 \\
\hline \multirow{2}{*}{6} & \multirow{2}{*}{ Kitaura 2} & 13 & Gantsu River & 3.1 & 0.1 & 0.09 & 0.07 & 0.07 & 0.08 \\
\hline & & 14 & (Direct Discharge) & - & 1.49 & 1.48 & 0.84 & 0.76 & 0.64 \\
\hline \multirow{3}{*}{7} & \multirow{3}{*}{$\begin{array}{l}\text { Sotona- } \\
\text { Sakaura }\end{array}$} & 15 & Yogoshi River & 1.70 & 1.28 & 1.13 & 1.13 & 1.06 & 0.88 \\
\hline & & 16 & Maekawa River & 0.90 & 0.06 & 0.05 & 0.04 & 0.04 & 0.05 \\
\hline & & 17 & Hitachi-Tone River & - & 0.67 & 0.71 & 0.60 & 0.48 & 0.46 \\
\hline
\end{tabular}


economic activity in the catchment area and the amount of water flowing decreases as compared to the amount of water pollutants flowing from each river as the reduction rate tightens more than $38 \%$. This result shows that the water quality of rivers is affected by the economic activity of catchments area, and large stagnation of economic activity worsens the water quality of rivers.

Average T-N concentration at the river mouth in Case 37 is shown in Table 9. It this simulation, $\mathrm{T}-\mathrm{N}$ concentration of the river decreased by $2.64 \mathrm{mg} / \mathrm{L}$ on an average. Particularly,that of Hokota River was decreased the most $(5.2 \mathrm{mg} / \mathrm{L})$.

\subsection{Budget Allotment}

In Figure 8, we show the accumulation of budget allotment in Case 0 to 37. According to the results of this simulation, the measured cost for household wastewater generation source and water pollutant direct removal became larger as the reduction rate becomes larger. This result shows that we should consider controlling water pollutants emitted from household as most important, when the reduction rate is made larger.

\subsection{Sectoral Change in Budget Allotment}

Sectoral change in the budget allotment for each policy in Case 30, Case 35, and Case 37 are shown in Figs. 9-11. It is interesting that the higher the reduction rate becomes, the larger the peak of the budget expenditure to the measure for the household wastewater generation source that was seen to be realized one year earlier for each simulation and the amount disbursed became larger and larger. The budget allotment for measures against industrial activity generation source was derived in each simulation for the Ono River basin. Although the Ono River basin has the largest rate of population growth in the target area, its per capita scale of financial affairs is small. The

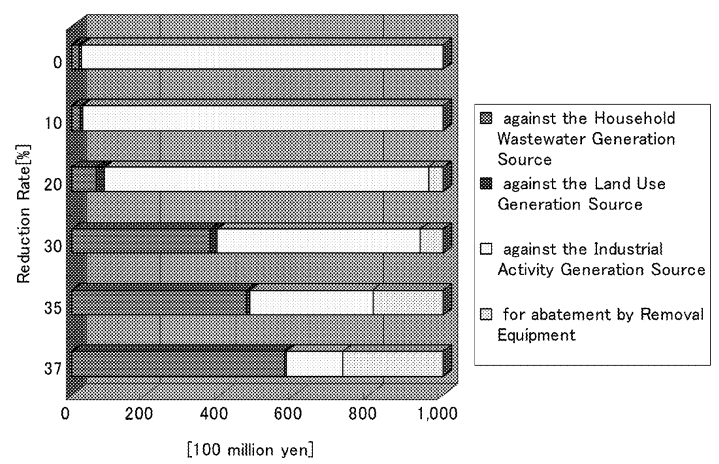

Fig. 8 Accumulated amount of budget allotment

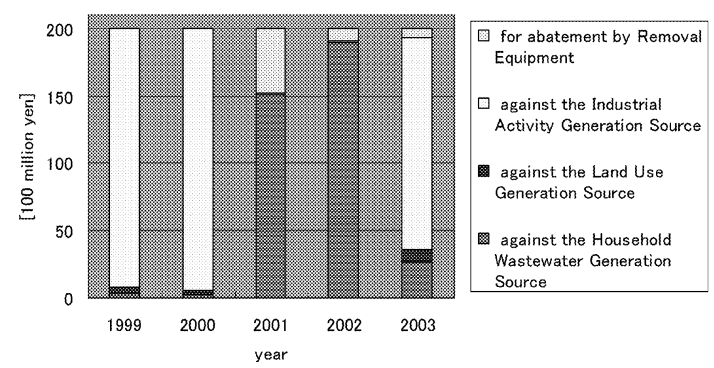

Fig. 9 Sectoral change in budget allotment of Case 30 


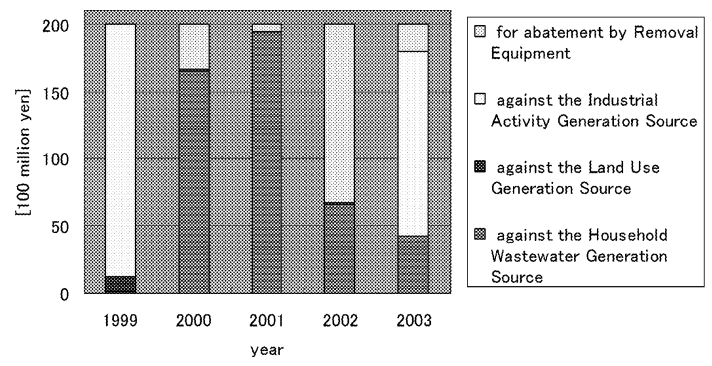

Fig. 10 Sectoral change in budget allotment of Case 35

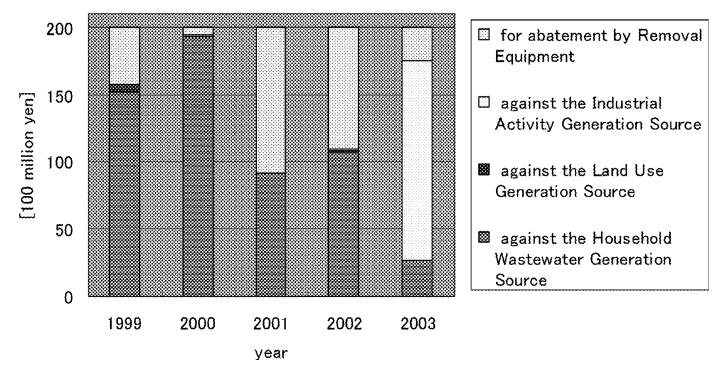

Fig. 11 Sectoral change in budget allotment of Case 37

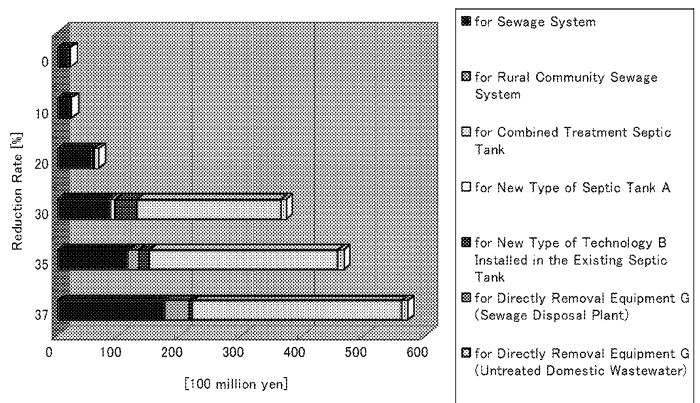

Fig. 12 Accumulation of budget allotment for the measure against household wastewater generation source

area is also behind in installation of a advanced household wastewater disposal system. Even in this simulation since the financial scale was small, installation of an advanced household wastewater disposal system did not keep up with the increase in population and the working capital reduction policywas choosen. By adopting this policy, the production activity of the industry in the Ono River basin will stagnate and will bring a large inequality in the industrial balance with other areas. Therefore, although a problem may be created from the viewpoint of fairness, it seems that Ibaraki Prefecture must adopt policies to increase the rate of subsidy to install an advanced household wastewater disposal system to this area.

\subsection{The Measure for the Household Wastewater Generation Source}

The budget expenses to the household wastewater generation source are shown in Fig. 12 for Case $0,10,20,30,35$ and 37 . In the reduction rates made to $30 \%$ or more, a largest budget for 
household wastewater generation source was assigned to the installation or maintenance/management for Directly Removal Equipment $G$ which treats the untreated domestic wastewater. This result shows that most important factor to reduce water pollutants from the household wastewater generation source is reduction of water pollutants discharged by the untreated domestic wastewater system. Installation of new technology $\mathrm{A}$ attached to the existing septic tank type was not chosen at all, but similar type of new technology B was chosen in the simulation. This new technology B had a high $\mathrm{T}-\mathrm{N}$ removal capability, while it was inferior to new technology $\mathrm{A}$ in the capability to remove $\mathrm{T}-\mathrm{P}$ and COD. This result also shows that nitrogen is difficult to remove and we should consider the reduction of $\mathrm{T}-\mathrm{N}$ as the most important factor.

\subsection{Measures Against the Water Pollutant Emissions from Dairy Farming and Pig Farming Industry}

The budget expenses for the measures against water pollutant emissions from the dairy farming industry in Case 37 are shown in Table 10. The budget expenses for the measures against water pollutant emissions from the pig farming industry are shown in Table 11. Direct removal system $\mathrm{F}$ was set up in municipalities in which the dairy farming industry and the pig farming industry were active. However, the amount of investment for installation of removal system was not derived in proportion to the amount of production of both industries. For instance, the largest construction investments for direct removal system $\mathrm{F}$ in the dairy farming industry was for Iwase town which is fifth in production for this industry. The following reasons are enumerated for this result. At first, dairy farming industry and pig farming industry has the largest $\mathrm{T}-\mathrm{N}$ emission coefficient. Second, Sakuragawa basin emits the largest amount of nitrogen into the catchment area of Lake Kasumigaura. Moreover, Iwase town has much greater production in the dairy farming industry than any other municipality in the basin. It is interesting that there are both an area where a budget is assigned to investment for construction of direct removal system $\mathrm{F}$ and an area where a budget is assigned to the subsidy for capital reduction. This result shows that the contribution to the water pollution by wastewater from stock raising is higher than ever considered, and the efficiency of the new technologies is still not sufficient to treat the high concentrations of wastewater. It also shows that the most important factor for the development of new technologies in future is how to enable treatment of wastewater with higher concentrations of pollutants.

\section{Conclusion}

When we adopted a policy that introduces new technology to improve the water quality, the policy was selected as a very effective tool to reduce environmental pollutants in all simulations. The introduction of the new technology raised the rate of pollutant reduction by $6 \%$ as compared to not adopting. Moreover, when introduction of the new technology reduced the rate by $33 \%$, the objective value had a difference of about 1.4 trillion yen as compared to when not introduced.

In order to reduce the pollutants that flow into Kasumigaura while maximizing GRP, this research has been made it clear that Ibaraki Prefecture should distribute a budget for policies to reduce the water pollutants established in 1999 to 2003 by following the priorities below.

[The Order of Priorities]

I. Measures against the household wastewater generation sources

(Budget required for 5 years to carry out a $37 \%$ reduction rate $=57,200$ million yen)

II. Installation of water pollutant direct removal equipment on rivers and Lake Kasumigaura

(Budget required for 5 years to carry out a $37 \%$ reduction rate $=27,100$ million yen)

III. Measures against the industrial activity generation sources

(Budget required for 5 years to carry out a $37 \%$ reduction rate $=15,100$ million yen)

IV. Measures against the non-point generation sources

(Budget required for 5 years to carry out a $37 \%$ reduction rate $=600$ million yen) 
Table 10. The water pollutant curtailment policy adopted by the dairy farming industry (Case 37 )

\begin{tabular}{|c|c|c|c|c|c|c|c|c|c|c|}
\hline \multicolumn{2}{|r|}{ Water Areas } & \multicolumn{2}{|r|}{ Rivers } & \multicolumn{2}{|c|}{$\begin{array}{l}\text { Cities, Towns and } \\
\text { Villages }\end{array}$} & \multicolumn{3}{|c|}{ Direct Removal System F } & \multicolumn{2}{|c|}{$\begin{array}{l}\text { Amount of Subsidy } \\
\text { for Reduction of } \\
\text { Capital Stock }\end{array}$} \\
\hline No. & Name & No. & Name & No. & Name & $\begin{array}{l}\text { Construction } \\
\text { Year }\end{array}$ & $\begin{array}{l}\text { Amount of } \\
\text { construction } \\
\text { investment } \\
\text { (million yen) }\end{array}$ & $\underset{\text { Unit }}{\text { Number of }}$ & Year & $\begin{array}{c}\text { Amount of } \\
\text { Subsidy } \\
(100 \text { million } \\
\text { yen })\end{array}$ \\
\hline \multirow[t]{11}{*}{1} & \multirow[t]{11}{*}{ Coast of Tsuchiura } & \multirow[t]{10}{*}{1} & \multirow[t]{10}{*}{ Sakura River } & 1 & Iwase Town & 2002 & 68.63 & 4 & \multirow{2}{*}{$\begin{array}{l}- \\
-\end{array}$} & - \\
\hline & & & & 2 & Yamato & 2002 & 0.66 & (1) & & - \\
\hline & & & & 3 & Makabe & - & 0 & - & \multirow{2}{*}{$\begin{array}{l}- \\
-\end{array}$} & - \\
\hline & & & & 4 & Akeno Town & 2002 & 0.88 & (1) & & \multirow{2}{*}{$\begin{array}{l}- \\
-\end{array}$} \\
\hline & & & & 5 & Kyowa & - & 0 & - & \multirow{2}{*}{-} & \\
\hline & & & & 6 & Shimodate & 2002 & 0.12 & (1) & & \multirow{5}{*}{$\begin{array}{r}- \\
- \\
- \\
9.15 \\
-\end{array}$} \\
\hline & & & & 7 & Shimotsuma & - & 0 & - & \multirow{4}{*}{$\begin{array}{c}- \\
- \\
2003\end{array}$} & \\
\hline & & & & 8 & Tsukuba City & 2002 & 3.06 & (1) & & \\
\hline & & & & 9 & Niihari & - & 0 & - & & \\
\hline & & & & 10 & Tsuchiura & - & 0 & - & & \\
\hline & & 2 & Seimei River & 11 & Miho Village & 2002 & 1.18 & (1) & - & - \\
\hline \multirow[t]{5}{*}{2} & \multirow[t]{5}{*}{ Coast of Takasaki } & \multirow[t]{2}{*}{3} & \multirow[t]{2}{*}{ Koise River } & 12 & Chiyoda & - & 0 & - & \multirow{2}{*}{$\begin{array}{c}- \\
2003 \\
\end{array}$} & - \\
\hline & & & & 13 & Yasato Town & - & 0 & - & & 39.24 \\
\hline & & 4 & Sonobe River & 14 & Ishioka City & - & 0 & - & - & - \\
\hline & & & & 15 & Tamari & - & 0 & - & - & - \\
\hline & & 5 & Kajinashi River & 16 & Tamatsukuri Town & 2002 & 2.25 & (1) & - & - \\
\hline 3 & Center of the Lake & 6 & Ono River & 17 & Kukizaki & 2002 & 0.25 & (1) & - & - \\
\hline & & & & 18 & Ushiku City & 2002 & 2.31 & (1) & - & - \\
\hline & & & & 19 & Ryugasaki & - & 0 & - & - & - \\
\hline & & & & 20 & Ami Town & - & 0 & - & - & - \\
\hline & & & & 21 & Edosaki & - & 0 & - & - & - \\
\hline & & & & 22 & Sakuragawa & - & 0 & - & - & - \\
\hline & & 7 & Ichinose River & 23 & Kasumigaura Town & - & 0 & - & - & - \\
\hline 4 & Asou & 8 & Shin-Tone River & 24 & Tone Town & 2002 & 0.23 & (1) & - & - \\
\hline & & & & 25 & Kawachi & - & 0 & - & - & - \\
\hline & & & & 26 & Shin-Tone & 2002 & 0.51 & (1) & - & - \\
\hline & & & & 27 & Azuma Town & 2002 & 2.59 & (1) & - & - \\
\hline 5 & Kitaura (1) & 9 & Hokota River & 28 & Asahi Village & - & 0 & - & - & - \\
\hline & & 10 & Tomoe River & 29 & Iwama Town & 2002 & 0.75 & (1) & - & - \\
\hline & & & & 30 & Minori Town & - & 0 & - & 2003 & 89.35 \\
\hline & & & & 31 & Ibaraki Town & 2002 & 0.6 & (1) & - & - \\
\hline & & & & 32 & Ogawa Town & 2002 & 11.04 & (1) & - & - \\
\hline & & & & 33 & Hokota Town & - & 0 & - & - & - \\
\hline & & 11 & Yamada River & 34 & Kitaura Town & - & 0 & - & - & - \\
\hline & & 12 & (Direct Discharge) & 35 & Taiyo Village & 2002 & 0.88 & (1) & - & - \\
\hline 6 & Kitaura (2) & 13 & Gantsu River & 36 & Asou Town & 2002 & 2.13 & (1) & - & - \\
\hline & & 14 & (Direct Discharge) & 37 & Kashima City & - & 0 & - & - & - \\
\hline 7 & Sotona-Sakaura & 15 & Yogoshi River & 38 & Ushibori Town & 2002 & 0.53 & (1) & - & - \\
\hline & & 16 & Maekawa River & 39 & Itako Town & - & 0 & - & - & - \\
\hline & & 17 & Hitachi-Tone River & 40 & Hasaki Town & - & 0 & - & - & - \\
\hline & & & & 41 & Kamisu & - & 0 & - & - & - \\
\hline- & - & - & - & - & Total & - & 98.57 & (21) & - & 137.74 \\
\hline
\end{tabular}


Table 11. The water pollutant curtailment policy adopted by the pig farming industry (Case-37)

\begin{tabular}{|c|c|c|c|c|c|c|c|c|c|c|}
\hline \multicolumn{2}{|r|}{ Water Areas } & \multicolumn{2}{|r|}{ Rivers } & \multicolumn{2}{|c|}{$\begin{array}{l}\text { Cities, Towns and } \\
\text { Villages }\end{array}$} & \multicolumn{3}{|c|}{ Direct Removal System F } & \multicolumn{2}{|c|}{$\begin{array}{l}\text { Amount of Subsidy } \\
\text { for Reduction of } \\
\text { Capital Stock }\end{array}$} \\
\hline No. & Name & No. & Name & No. & Name & $\begin{array}{l}\text { Construction } \\
\text { Year }\end{array}$ & $\begin{array}{l}\text { Amount of } \\
\text { construction } \\
\text { investment } \\
\text { (million yen) }\end{array}$ & $\underset{\text { Unit }}{\text { Number of }}$ & Year & $\begin{array}{l}\text { Amount of } \\
\text { Subsidy } \\
(100 \text { million } \\
\text { yen })\end{array}$ \\
\hline \multirow[t]{11}{*}{1} & \multirow[t]{11}{*}{ Coast of Tsuchiura } & \multirow[t]{10}{*}{1} & \multirow[t]{10}{*}{ Sakura River } & 1 & Iwase Town & 2002 & 0 & - & \multirow{10}{*}{$\begin{array}{l}- \\
- \\
- \\
- \\
- \\
- \\
- \\
003 \\
- \\
-\end{array}$} & \multirow{10}{*}{$\begin{array}{c}- \\
- \\
- \\
- \\
- \\
- \\
- \\
2.42 \\
- \\
-\end{array}$} \\
\hline & & & & 2 & Yamato & 2002 & 0 & - & & \\
\hline & & & & 3 & Makabe & - & 0.86 & (1) & & \\
\hline & & & & 4 & Akeno Town & 2002 & 0 & - & & \\
\hline & & & & 5 & Kyowa & - & 1.18 & (1) & & \\
\hline & & & & 6 & Shimodate & 2002 & 0 & - & & \\
\hline & & & & 7 & Shimotsuma & - & 0.06 & (1) & & \\
\hline & & & & 8 & Tsukuba City & 2002 & 0 & - & & \\
\hline & & & & 9 & Niihari & - & 2.2 & (1) & & \\
\hline & & & & 10 & Tsuchiura & - & 7.48 & (1) & & \\
\hline & & 2 & Seimei River & 11 & Miho Village & 2002 & 0 & - & - & - \\
\hline \multirow[t]{5}{*}{2} & \multirow[t]{5}{*}{ Coast of Takasaki } & \multirow[t]{2}{*}{3} & \multirow[t]{2}{*}{ Koise River } & 12 & Chiyoda & - & 2.13 & (1) & \multirow{2}{*}{$\begin{array}{l}- \\
-\end{array}$} & \multirow{2}{*}{-} \\
\hline & & & & 13 & Yasato Town & - & 5.97 & (1) & & \\
\hline & & \multirow[t]{2}{*}{4} & \multirow[t]{2}{*}{ Sonobe River } & 14 & Ishioka City & - & 4.41 & (1) & \multirow{2}{*}{$\begin{array}{l}- \\
-\end{array}$} & \multirow{2}{*}{-} \\
\hline & & & & 15 & Tamari & - & 2.76 & (1) & & \\
\hline & & 5 & Kajinashi River & 16 & Tamatsukuri Town & 2002 & 0 & - & - & - \\
\hline \multirow[t]{7}{*}{3} & Center of the Lake & 6 & Ono River & 17 & Kukizaki & 2002 & 0 & - & - & - \\
\hline & & & & 18 & Ushiku City & 2002 & 0 & - & - & - \\
\hline & & & & 19 & Ryugasaki & - & 2.95 & (1) & - & - \\
\hline & & & & 20 & Ami Town & - & 5.14 & (1) & - & - \\
\hline & & & & 21 & Edosaki & - & 1.06 & (1) & - & - \\
\hline & & & & 22 & Sakuragawa & - & 0.33 & (1) & - & - \\
\hline & & 7 & Ichinose River & 23 & Kasumigaura Town & - & 3.3 & (1) & - & - \\
\hline 4 & Asou & 8 & Shin-Tone River & 24 & Tone Town & 2002 & 0 & - & - & - \\
\hline & & & & 25 & Kawachi & - & 0.44 & (1) & - & - \\
\hline & & & & 26 & Shin-Tone & 2002 & 0 & - & - & - \\
\hline & & & & 27 & Azuma Town & 2002 & 0 & - & - & - \\
\hline 5 & Kitaura (1) & 9 & Hokota River & 28 & Asahi Village & - & 1.55 & (1) & - & - \\
\hline & & 10 & Tomoe River & 29 & Iwama Town & 2002 & 0 & - & - & - \\
\hline & & & & 30 & Minori Town & - & 7.67 & (1) & - & - \\
\hline & & & & 31 & Ibaraki Town & 2002 & 0 & - & 2003 & 1.48 \\
\hline & & & & 32 & Ogawa Town & 2002 & 0 & - & - & - \\
\hline & & & & 33 & Hokota Town & - & 7.35 & (1) & - & - \\
\hline & & 11 & Yamada River & 34 & Kitaura Town & - & 3.21 & (1) & - & - \\
\hline & & 12 & (Direct Discharge) & 35 & Taiyo Village & 2002 & 0 & - & - & - \\
\hline 6 & Kitaura (2) & 13 & Gantsu River & 36 & Asou Town & 2002 & 0 & - & - & - \\
\hline & & 14 & (Direct Discharge) & 37 & Kashima City & - & 4.11 & (1) & - & - \\
\hline 7 & Sotona-Sakaura & 15 & Yogoshi River & 38 & Ushibori Town & 2002 & 0 & 0 & - & - \\
\hline & & 16 & Maekawa River & 39 & Itako Town & - & 0.47 & (1) & - & - \\
\hline & & 17 & Hitachi-Tone River & 40 & Hasaki Town & - & 4.32 & (1) & - & - \\
\hline & & & & 41 & Kamisu & - & 8.12 & (1) & - & - \\
\hline- & - & - & - & - & Total & - & 77.05 & $(23)$ & - & 3.9 \\
\hline
\end{tabular}


In this study, it was found that the efficiency of new technologies is still not sufficient to treat wastewater with high concentrations of pollutants, and that the most important factor for the development of new technology in the future is how to enable treatment of wastewater with higher concentrations, especially of total nitrogen. In addition, to reduce water pollutants emitted from the stock raising industry, we should develop a water quality improvement policy with usefulness for livestock feces and urine, such as power generation using biomass energy. The dialogue related to these project has already began in the city areas that integrate industry-university-government cooperation promotion business through "the Lake Kasumigaura Biomass Recycling Development Project".

\section{Appendix}

Table A-1. Numerical Data for a New Type of Septic Tank

\begin{tabular}{|l|l|c|c|c|c|c|}
\hline \multicolumn{1}{|c|}{ Name } & Principle & $\begin{array}{c}\text { Construction } \\
\text { Cost (million } \\
\text { yen/person) }\end{array}$ & $\begin{array}{c}\text { BOD Emission } \\
\text { Coefficient } \\
\text { (interms of COD) } \\
\text { (kg/personyear) }\end{array}$ & $\begin{array}{c}\text { COD Emission } \\
\text { Coefficient } \\
\text { (kg/person-year) }\end{array}$ & $\begin{array}{c}\text { T-N Emission } \\
\text { Coefficient } \\
\text { (kg/person-year) }\end{array}$ & $\begin{array}{c}\text { T-P Emission } \\
\text { Coefficient } \\
\text { (kg/person-year) }\end{array}$ \\
\hline $\begin{array}{l}\text { New Type of Septic } \\
\text { Tank A }\end{array}$ & $\begin{array}{l}\text { Biological } \\
\text { Processing }\end{array}$ & 0.40 & 0.67 & 1.06 & 0.65 & 0.42 \\
\hline $\begin{array}{l}\text { New Type of Septic } \\
\text { Tank B }\end{array}$ & $\begin{array}{l}\text { Biological } \\
\text { Processing }\end{array}$ & 0.29 & 0.82 & 0.82 & 0.88 & 0.09 \\
\hline
\end{tabular}

Table A-2. Numerical Data of a New Type of Technology Installed in Existing Septic Tanks

\begin{tabular}{|c|c|c|c|c|c|c|c|}
\hline Name & Principle & $\begin{array}{c}\text { Construction } \\
\text { Cost (million } \\
\text { yen/person) }\end{array}$ & $\begin{array}{c}\text { Maintenance } \\
\text { Cost (million } \\
\text { yen/personyear) }\end{array}$ & $\begin{array}{c}\text { Energy Charge } \\
\text { (million yen/ } \\
\text { person-year) }\end{array}$ & $\begin{array}{c}\text { COD Abatement } \\
\text { Coefficient } \\
\text { (kg/person-year) }\end{array}$ & $\begin{array}{c}\text { T-N Abatement } \\
\text { Coefficient } \\
\text { (kg/person-year) }\end{array}$ & $\begin{array}{c}\text { T-P Abatement } \\
\text { Coefficient } \\
\text { (kg/person-year) }\end{array}$ \\
\hline $\begin{array}{c}\text { New Technology } \\
\text { Installed in } \\
\text { Existing Septic } \\
\text { Tank A }\end{array}$ & $\begin{array}{c}\text { Phosphorous } \\
\text { Removal }\end{array}$ & 0.08 & 0.038 & 0.007 & 0 & 0 \\
\hline $\begin{array}{c}\text { New Technology } \\
\text { Installed in } \\
\text { Existing Septic } \\
\text { Tank B }\end{array}$ & $\begin{array}{c}\text { Phosphorous } \\
\text { Removal } \\
\text { Denitrification }\end{array}$ & 0.035 & 0 & 0 & 0 & 0.033 \\
\hline
\end{tabular}

Table A-3. The Numerical Data of Direct Removal Equipment (Setting on the Riverside)

\begin{tabular}{|c|c|c|c|c|c|c|c|c|c|}
\hline Name & Principle & $\begin{array}{c}\text { Scale } \\
\text { (10 thousand } \\
\text { L/year) }\end{array}$ & $\begin{array}{c}\text { Construction } \\
\text { Cost } \\
\text { (million } \\
\text { yen/unit) }\end{array}$ & $\begin{array}{l}\text { Maintenance } \\
\quad \text { Cost } \\
\text { (million yen/ } \\
\text { construction } \\
\text { cost million } \\
\text { yen year) }\end{array}$ & \begin{tabular}{|c} 
Energy Charge \\
(million yen/ \\
construction \\
cost million \\
yen year)
\end{tabular} & $\begin{array}{c}\text { BOD } \\
\text { Abatement } \\
\text { Coefficient (in } \\
\text { terms of } \\
\text { COD) (kg/ } \\
\text { construction } \\
\text { cost million } \\
\text { yen year) }\end{array}$ & $\begin{array}{c}\text { COD } \\
\text { Abatement } \\
\text { Coefficient } \\
\quad(\mathrm{kg} / \\
\text { construction } \\
\text { cost million } \\
\text { yen year) }\end{array}$ & $\begin{array}{c}\mathrm{T}-\mathrm{N} \\
\text { Abatement } \\
\text { Coefficient } \\
\quad \text { (kg/ } \\
\text { construction } \\
\text { cost million } \\
\text { yen year) }\end{array}$ & $\begin{array}{c}\text { T-P } \\
\text { Abatement } \\
\text { Coefficient } \\
\text { (kg/ } \\
\text { construction } \\
\text { cost million } \\
\text { yen year) }\end{array}$ \\
\hline $\begin{array}{l}\text { Direct } \\
\text { Removal } \\
\text { System A }\end{array}$ & $\begin{array}{l}\text { Biological } \\
\text { Processing }\end{array}$ & 365 & 20 & 0.04 & 0 & 11.747 & 8.03 & 1.46 & 0.329 \\
\hline $\begin{array}{l}\text { Direct } \\
\text { Removal } \\
\text { System B }\end{array}$ & $\begin{array}{l}\text { Biological } \\
\text { Processing }\end{array}$ & 10,950 & 6 & - & - & - & 28.1 & 8.2 & 0.4 \\
\hline $\begin{array}{l}\text { Direct } \\
\text { Removal } \\
\text { System C }\end{array}$ & $\begin{array}{l}\text { Biological+ } \\
\text { Chemical } \\
\text { Processing }\end{array}$ & 5,110 & 80 & 0.009 & 0.008 & 11.421 & 0 & 1.501 & 0.287 \\
\hline $\begin{array}{l}\text { Direct } \\
\text { Removal } \\
\text { System F }\end{array}$ & $\begin{array}{l}\text { Electrochemical } \\
\text { Processing }\end{array}$ & 1,022 & 16.7 & 0.77 & 0.022 & - & 26.9 & 1.39 & 0.2 \\
\hline $\begin{array}{l}\text { Direct } \\
\text { Removal } \\
\text { System G }\end{array}$ & $\begin{array}{l}\text { Electrochemical } \\
\text { Processing }\end{array}$ & 263 & 25 & 0.036 & 0.018 & 6.766 & 3.311 & 2.541 & 0.468 \\
\hline
\end{tabular}


Table A-4. Numerical Data for Direct Removal Equipment (Setting on the Lakeside)

\begin{tabular}{|c|c|c|c|c|c|c|c|c|c|}
\hline Name & Principle & $\begin{array}{c}\text { Scale } \\
\text { (10 thousand } \\
\text { L/year) }\end{array}$ & $\begin{array}{l}\text { Construction } \\
\text { Cost (million } \\
\text { yen/unit) }\end{array}$ & $\begin{array}{c}\text { Energy Charge } \\
\text { (million yen/ } \\
\text { construction } \\
\text { cost million } \\
\text { yen year) }\end{array}$ & $\begin{array}{c}\text { Maintenance } \\
\text { Cost (million } \\
\text { yen/ } \\
\text { construction } \\
\text { cost million } \\
\text { yen year) }\end{array}$ & \begin{tabular}{|c|} 
BOD \\
Abatement \\
Coefficient (in \\
terms of COD) \\
(kg/ \\
construction \\
cost million \\
yen year)
\end{tabular} & $\begin{array}{c}\text { COD } \\
\text { Abatement } \\
\text { Coefficient } \\
\quad(\mathrm{kg} / \\
\text { construction } \\
\text { cost million } \\
\text { yen year) }\end{array}$ & $\begin{array}{l}\mathrm{T}-\mathrm{N} \\
\text { Abatement } \\
\text { Coefficient } \\
\quad \text { (kg/ } \\
\text { construction } \\
\text { cost million } \\
\text { yen year) }\end{array}$ & $\begin{array}{l}\text { T-P } \\
\text { Abatement } \\
\text { Coefficient } \\
\quad \text { kg/ } \\
\text { construction } \\
\text { cost million } \\
\text { yen year) }\end{array}$ \\
\hline $\begin{array}{l}\text { Direct } \\
\text { Removal } \\
\text { System B }\end{array}$ & $\begin{array}{l}\text { Biological } \\
\text { Processing }\end{array}$ & 10,950 & 6 & - & - & - & 28.1 & 8.2 & 0.4 \\
\hline $\begin{array}{l}\text { Direct } \\
\text { Removal } \\
\text { System D }\end{array}$ & $\begin{array}{l}\text { Biological+ } \\
\text { Chemical } \\
\text { Processing }\end{array}$ & 18,250 & 20 & 0.027 & 0.025 & 0 & 9.125 & 9.125 & 0 \\
\hline $\begin{array}{l}\text { Direct } \\
\text { Removal } \\
\text { System E }\end{array}$ & $\begin{array}{l}\text { Biological } \\
\text { Processing }\end{array}$ & $\begin{array}{c}167.96 \\
(\mathrm{BOD} \\
\text { abatement } \\
\mathrm{kg} / \text { year) }\end{array}$ & 10.018 & 0 & 167.97 & 0 & 0 & & \\
\hline $\begin{array}{l}\text { Direct } \\
\text { Removal } \\
\text { System F }\end{array}$ & $\begin{array}{l}\text { Electrochemical } \\
\text { Processing }\end{array}$ & 1,022 & 16.7 & 0.77 & 0.022 & - & 26.9 & 1.39 & 0.2 \\
\hline $\begin{array}{l}\text { Direct } \\
\text { Removal } \\
\text { System G }\end{array}$ & $\begin{array}{l}\text { Electrochemical } \\
\text { Processing }\end{array}$ & 263 & 25 & 0.036 & 0.018 & 6.766 & 3.311 & 2.541 & 0.468 \\
\hline
\end{tabular}

Table A-5. Numerical Data for Direct Removal Equipment (Treatment of Stock Raising Wastewater)

\begin{tabular}{|c|c|c|c|c|c|c|c|c|}
\hline Name & Principle & $\begin{array}{c}\text { Scale } \\
\text { (10 thousand } \\
\text { L/year) }\end{array}$ & $\begin{array}{c}\text { Construction } \\
\text { Cost } \\
\text { (million yen/ } \\
\text { unit) }\end{array}$ & $\begin{array}{l}\text { Energy Charge } \\
\text { (million yen/ } \\
\text { construction } \\
\text { cost million } \\
\text { yen year) }\end{array}$ & $\begin{array}{c}\text { Maintenance } \\
\text { Cost } \\
\text { (million yen/ } \\
\text { construction } \\
\text { cost million } \\
\text { yen year) }\end{array}$ & $\begin{array}{c}\text { COD } \\
\text { Abatement } \\
\text { Coefficient }(\mathrm{kg} / \\
\text { construction } \\
\text { cost million } \\
\text { yen year) }\end{array}$ & $\begin{array}{c}\mathrm{T}-\mathrm{N} \\
\text { Abatement } \\
\text { Coefficient }(\mathrm{kg} / \\
\text { construction } \\
\text { cost million } \\
\text { yen year) }\end{array}$ & $\begin{array}{c}\text { T-P } \\
\text { Abatement } \\
\text { Coefficient }(\mathrm{kg} / \\
\text { construction } \\
\text { cost million } \\
\text { yen year) }\end{array}$ \\
\hline $\begin{array}{l}\text { Direct } \\
\text { Removal } \\
\text { System F }\end{array}$ & $\begin{array}{l}\text { Electrochemical } \\
\text { Processing }\end{array}$ & 1,095 & 17.9 & 0.760 & 0.022 & 13853.20 & 960.400 & 2.310 \\
\hline
\end{tabular}

Table A-6. Numerical Data for Direct Removal Equipment

(Treatment of Manufacturing Industry Wastewater)

\begin{tabular}{|c|c|c|c|c|c|c|c|c|}
\hline Name & Principle & $\begin{array}{c}\text { Scale } \\
\text { (10 thousand } \\
\text { L/year) }\end{array}$ & $\begin{array}{c}\text { Construction } \\
\text { Cost } \\
\text { (million } \\
\text { yen/unit) }\end{array}$ & $\begin{array}{c}\text { Energy Charge } \\
\text { (million yen/ } \\
\text { construction } \\
\text { cost million } \\
\text { yen year) }\end{array}$ & $\begin{array}{l}\text { Maintenance } \\
\text { Cost } \\
\text { (million yen/ } \\
\text { construction } \\
\text { cost million } \\
\text { yen year) }\end{array}$ & $\begin{array}{c}\text { COD } \\
\text { Abatement } \\
\text { Coefficient }(\mathrm{kg} / \\
\text { construction } \\
\text { cost million } \\
\text { yen year) }\end{array}$ & $\begin{array}{c}\mathrm{T}-\mathrm{N} \\
\text { Abatement } \\
\text { Coefficient }(\mathrm{kg} / \\
\text { construction } \\
\text { cost million } \\
\text { yen year) }\end{array}$ & $\begin{array}{c}\mathrm{T}-\mathrm{P} \\
\text { Abatement } \\
\text { Coefficient (kg/ } \\
\text { construction } \\
\text { cost million } \\
\text { yen year) }\end{array}$ \\
\hline $\begin{array}{l}\text { Direct } \\
\text { Removal } \\
\text { System F }\end{array}$ & $\begin{array}{l}\text { Electrochemical } \\
\text { Processing }\end{array}$ & 365 & 31.6 & 1.430 & 0.042 & 4447.00 & 39.70 & 26.20 \\
\hline $\begin{array}{l}\text { Direct } \\
\text { Removal } \\
\text { System G }\end{array}$ & $\begin{array}{l}\text { Electrochemical } \\
\text { Processing }\end{array}$ & 3,650 & 70.0 & 0.049 & 0.031 & 1006.35 & 2372.50 & 1715.50 \\
\hline
\end{tabular}

Table A-7. Numerical Data for Direct Removal Equipment (Treatment of Untreated Domestic Wastewater)

\begin{tabular}{|l|l|c|c|c|c|c|c|}
\hline Name & Principle & $\begin{array}{c}\text { Scale } \\
\text { (10 thousand } \\
\text { L/year) }\end{array}$ & $\begin{array}{c}\text { Construction } \\
\text { Cost } \\
\text { (million } \\
\text { yen/unit) }\end{array}$ & $\begin{array}{c}\text { Energy Charge } \\
\text { (million yen/ } \\
\text { construction } \\
\text { cost million } \\
\text { yen year) }\end{array}$ & $\begin{array}{c}\text { Maintenance } \\
\text { Cost } \\
\text { (million yen/ } \\
\text { construction } \\
\text { cost million } \\
\text { yen year) }\end{array}$ & $\begin{array}{c}\text { COD } \\
\text { Abatement } \\
\text { Coefficient (kg/ } \\
\text { construction } \\
\text { cost million } \\
\text { yen year) }\end{array}$ & $\begin{array}{c}\mathrm{T}-\mathrm{N} \\
\text { Abatement } \\
\text { Coefficient (kg/ } \\
\text { construction } \\
\text { cost million } \\
\text { yen year) }\end{array}$ \\
$\begin{array}{c}\text { Abatement } \\
\text { constructiont (kg/ } \\
\text { cost million } \\
\text { yen year) }\end{array}$ \\
\hline $\begin{array}{l}\text { Direct } \\
\text { Removal } \\
\text { System G }\end{array}$ & $\begin{array}{l}\text { Electrochemical } \\
\text { Processing }\end{array}$ & 1,825 & 50.2 & 0.049 & 0.022 & 8.500 & 5.848 \\
\hline
\end{tabular}


Table A-8. Numerical Data for Direct Removal Equipment (Setting in the Sewage Disposal Plant)

\begin{tabular}{|c|c|c|c|c|c|c|c|c|c|}
\hline Name & Principle & $\begin{array}{c}\text { Scale } \\
\text { (10 thousand } \\
\text { L/year) }\end{array}$ & $\begin{array}{l}\text { Construction } \\
\text { Cost (million } \\
\text { yen/unit) }\end{array}$ & $\begin{array}{c}\text { Maintenance } \\
\text { Cost (million } \\
\quad \text { yen/ } \\
\text { construction } \\
\text { cost million } \\
\text { yen year) }\end{array}$ & $\begin{array}{l}\text { Energy Charge } \\
\text { (million yen/ } \\
\text { construction } \\
\text { cost million } \\
\text { yen year) }\end{array}$ & $\begin{array}{c}\text { BOD } \\
\text { Abatement } \\
\text { Coefficient } \\
\text { (in terms of } \\
\text { COD) (kg/ } \\
\text { construction } \\
\text { cost million } \\
\text { yen year) }\end{array}$ & $\begin{array}{c}\text { COD } \\
\text { Abatement } \\
\text { Coefficient } \\
\text { (kg/ } \\
\text { construction } \\
\text { cost million } \\
\text { yen year) }\end{array}$ & $\begin{array}{c}\mathrm{T}-\mathrm{N} \\
\text { Abatement } \\
\text { Coefficient } \\
\quad(\mathrm{kg} / \\
\text { construction } \\
\text { cost million } \\
\text { yen year) }\end{array}$ & $\begin{array}{c}\text { T-P } \\
\text { Abatement } \\
\text { Coefficient } \\
\text { (kg/ } \\
\text { construction } \\
\text { cost million } \\
\text { yen year) }\end{array}$ \\
\hline $\begin{array}{l}\text { Directly } \\
\text { Removal } \\
\text { System F }\end{array}$ & $\begin{array}{l}\text { Electrochemical } \\
\text { Processing }\end{array}$ & 365 & 31.6 & 1.430 & 0.042 & - & 4447.00 & 39.700 & 26.200 \\
\hline $\begin{array}{l}\text { Directly } \\
\text { Removal } \\
\text { System G }\end{array}$ & $\begin{array}{l}\text { Electrochemical } \\
\text { Processing }\end{array}$ & 3,650 & 70.0 & 0.049 & 0.031 & 3107.96 & 1006.35 & 2372.50 & 1715.50 \\
\hline $\begin{array}{l}\text { Directly } \\
\text { Removal } \\
\text { System H }\end{array}$ & $\begin{array}{l}\text { Condensation } \\
\text { Separation }\end{array}$ & 182,500 & 186.0 & 0.026 & 0.000 & 110.173 & 272.769 & 22.469 & 0.981 \\
\hline
\end{tabular}

Table A-9. Water pollutants Emission Coefficient of Hosehold Wastewater Generation Source

\begin{tabular}{|c|c|c|c|c|c|}
\hline Index & Area & Unit & COD & $\mathrm{T}-\mathrm{N}$ & $\mathrm{T}-\mathrm{P}$ \\
\hline \multirow{4}{*}{ Sewage System } & Kohoku-area & $\mathrm{kg} /$ person-year & 0.76 & 0.98 & 0.02 \\
\hline & Suigo-area & $\mathrm{kg} /$ person-year & 0.62 & 0.73 & 0.01 \\
\hline & Selected Environment & $\mathrm{kg} /$ person-year & 0.58 & 0.64 & 0.05 \\
\hline & Independent Public & $\mathrm{kg} /$ person-year & 0.58 & 0.64 & 0.05 \\
\hline Rural Community Sewage System & - & $\mathrm{kg} /$ person-year & 0.57 & 0.65 & 0.11 \\
\hline Combined Treatment Septic Tank & - & $\mathrm{kg} /$ person-year & 2.14 & 2.19 & 0.22 \\
\hline Treatment Septic Tank & - & $\mathrm{kg} /$ person-year & 1.29 & 2.79 & 0.24 \\
\hline \multirow{4}{*}{ Night Soil Septic Tank } & Kohoku & $\mathrm{kg} /$ person-year & 0.06 & 0.03 & 0.01 \\
\hline & Tikuhoku & $\mathrm{kg} /$ person-year & 0.02 & 0 & 0 \\
\hline & Itako-Ushibori & $\mathrm{kg} /$ person-year & 0.01 & 0.01 & 0 \\
\hline & Asou & $\mathrm{kg} /$ person-year & 0.01 & 0.01 & 0 \\
\hline Untreated Domestic Wastewater & - & $\mathrm{kg} /$ person-year & 5.72 & 0.93 & 0.13 \\
\hline
\end{tabular}

Table A-10. Water pollutants Emission Coefficient of Industrial Activity Generation Source

\begin{tabular}{|l|l|r|r|r|}
\hline \multicolumn{1}{|c|}{ Index } & \multicolumn{1}{c|}{ Unit } & COD & T-N & T-P \\
\hline Dairy Farming & $\mathrm{kg} /$ million yen-year & 20.72 & 20.69 & 0.16 \\
\hline Pig Farming & $\mathrm{kg} /$ million yen-year & 25.75 & 16.87 & 0.38 \\
\hline Fisheries & $\mathrm{kg} /$ million yen-year & 115 & 45.4 & 10 \\
\hline Manufacturing Industry & $\mathrm{kg} /$ million yen-year & 23.54 & 9.8 & 0.99 \\
\hline Other Industries & $\mathrm{kg} /$ million yen-year & 0 & 0 & 0 \\
\hline
\end{tabular}


Table A-11. Water pollutants Emission Coefficient of Land Use Generation Source

\begin{tabular}{|l|c|r|r|c|}
\hline \multicolumn{1}{|c|}{ Index } & Unit & COD & \multicolumn{1}{c|}{$\mathrm{T}-\mathrm{N}$} & $\mathrm{T}-\mathrm{P}$ \\
\hline Paddy Field & $\mathrm{kg} / \mathrm{km}^{2}$-year & 1003.5 & 1018.4 & 34.7 \\
\hline Rice Field & $\mathrm{kg} / \mathrm{km}^{2}$-year & 2416.3 & 841.3 & 30.5 \\
\hline Mountain Forest & $\mathrm{kg} / \mathrm{km}^{2}$-year & 1398 & 569.4 & 19.7 \\
\hline City Area & $\mathrm{kg} / \mathrm{km}^{2}$-year & 5584.5 & 876 & 65.7 \\
\hline Other Land Use & $\mathrm{kg} / \mathrm{km}^{2}$-year & 1377.9 & 649.7 & 25.4 \\
\hline Rain fall & $\mathrm{kg} / \mathrm{km}^{2}$-year & 2091.5 & 1124.2 & 47.5 \\
\hline
\end{tabular}

Table A-12. Input Coefficient

\begin{tabular}{|l|c|c|c|c|c|c|c|c|}
\hline & $\begin{array}{c}\text { Upland } \\
\text { Cropping }\end{array}$ & $\begin{array}{c}\text { Rice } \\
\text { Cropping }\end{array}$ & $\begin{array}{c}\text { Dairy } \\
\text { Farming }\end{array}$ & $\begin{array}{c}\text { Pig } \\
\text { Farming }\end{array}$ & Fisheries & $\begin{array}{c}\text { Manufacturing } \\
\text { Industry }\end{array}$ & $\begin{array}{c}\text { Other } \\
\text { Industries }\end{array}$ & $\begin{array}{c}\text { Sum of } \\
\text { Endogenous } \\
\text { Sector }\end{array}$ \\
\hline Upland Cropping & 0.0164 & 0.0164 & 0.0869 & 0.0869 & 0 & 0.0103 & 0.0009 & 0.00598 \\
\hline Rice Cropping & 0.0077 & 0.0077 & 0.0408 & 0.0408 & 0 & 0.0048 & 0.0004 & 0.0028 \\
\hline Dairy Farming & 0.0029 & 0.0029 & 0.0323 & 0.0323 & 0 & 0.0029 & 0.0001 & 0.0016 \\
\hline Pig Farming & 0.0047 & 0.0047 & 0.0528 & 0.0528 & 0 & 0.0047 & 0.0002 & 0.00261 \\
\hline Fisheries & 0 & 0 & 0 & 0 & 0.0805 & 0.0039 & 0.0004 & 0.00225 \\
\hline Manufacturing Industry & 0.126 & 0.126 & 0.2883 & 0.2883 & 0.1763 & 0.4085 & 0.1251 & 0.26067 \\
\hline Other Industries & 0.177 & 0.177 & 0.2264 & 0.2264 & 0.1732 & 0.1983 & 0.244 & 0.22105 \\
\hline Sumof Endogenous Sector & 0.3347 & 0.3347 & 0.7275 & 0.7275 & 0.43 & 0.6334 & 0.3711 & 0.49696 \\
\hline Sumof Gross Added Value & 0.6653 & 0.6653 & 0.2725 & 0.2725 & 0.57 & 0.3666 & 0.6289 & 0.50304 \\
\hline
\end{tabular}




\section{References}

[1] Aramaki, S. and Matsuo, T., "Relative probability evaluation of amount of water and water quality management measure by Water and a corruption substance income-and-outgo simulation", Journals of the Japan Society of Civil Engineers, No.601/VII-8, pp. 45-57, 1998

[2 ] Aramaki, S. and Matsuo, T., "A study on the creation technique of the flux used for a simulation of watershed management", Journals of the Japan Society of Civil Engineers, No.601/VII-8, pp. 23-33, 1998.

[ 3 ] Baumol, W.J. and Oates, W.E., "The Theory of Environmental Policy," Cambridge Univ. Press, 1988.

[4] Hirose, F. and Higano, Y., "A Simulation Analysis to Reduce Pollutants from the Catchment Area of Lake Kasumigaura," Studies in Regional Science, Vol. 30, No. 1, 2000, pp. 47-63

[5 ] Higano, Y. and Yoneta, A., "Economical Policies to Relieve Contamination of Lake Kaimigaura," Studies in Regional Science, Vol. 29, No. 3, 1998, pp. 205-218

[6] Inamori, Y., Sankai, T. and Sudou, R., "Development and Phosphorus Removal Advanced Technologies for Treating Back Gray Simultaneously," Journal of Resources and Environment, Vol. 34, No. 10, 1998, pp. 17-25.

[7] Mizunoya, T., "A Study on Evaluation of New Technology and Optimal Environmental Policy to Improve the Water Quality of Lake Kasumigaura," Doctoral dissertation for Division of Biosphere Resource Science and Technology, Graduate School of Life and Environmental Sciences, University of Tsukuba, 2002.

[ 8 ] Oka, T., "Welfare Economics and Environmental Policy," Iwanami Press, 1997.

[9] Takagi, A., "Economic Evaluation of The Water Quality Improvement Policy in The Closed Water Area," Studies for Environmental Systems, vol. 27, pp. 9-16, 1999.

[10] The Science and Technology Promotion Foundation of Ibaraki, "Environmental Preservation Measures Information Packet for Lake Kasumigaura," 2001.

[11] Yoshida, T., Aizaki, M., Asami, T. and Makishima, N., "Biological Nitrogen Fixation and Denitrification in Lake Kasumiga-ura, "Japanese Journal of Limnology, Vol. 40, No. 1, 1979, pp. $1-9$. 